Prepared in cooperation with the U.S. Department of Energy and Idaho Department of Water Resources

DOE/ID-22190

Radiochemical and Chemical Constituents in Water from Selected Wells and Springs from the Southern Boundary of the Idaho National Engineering and Environmental Laboratory to the Hagerman Area, Idaho, 2002

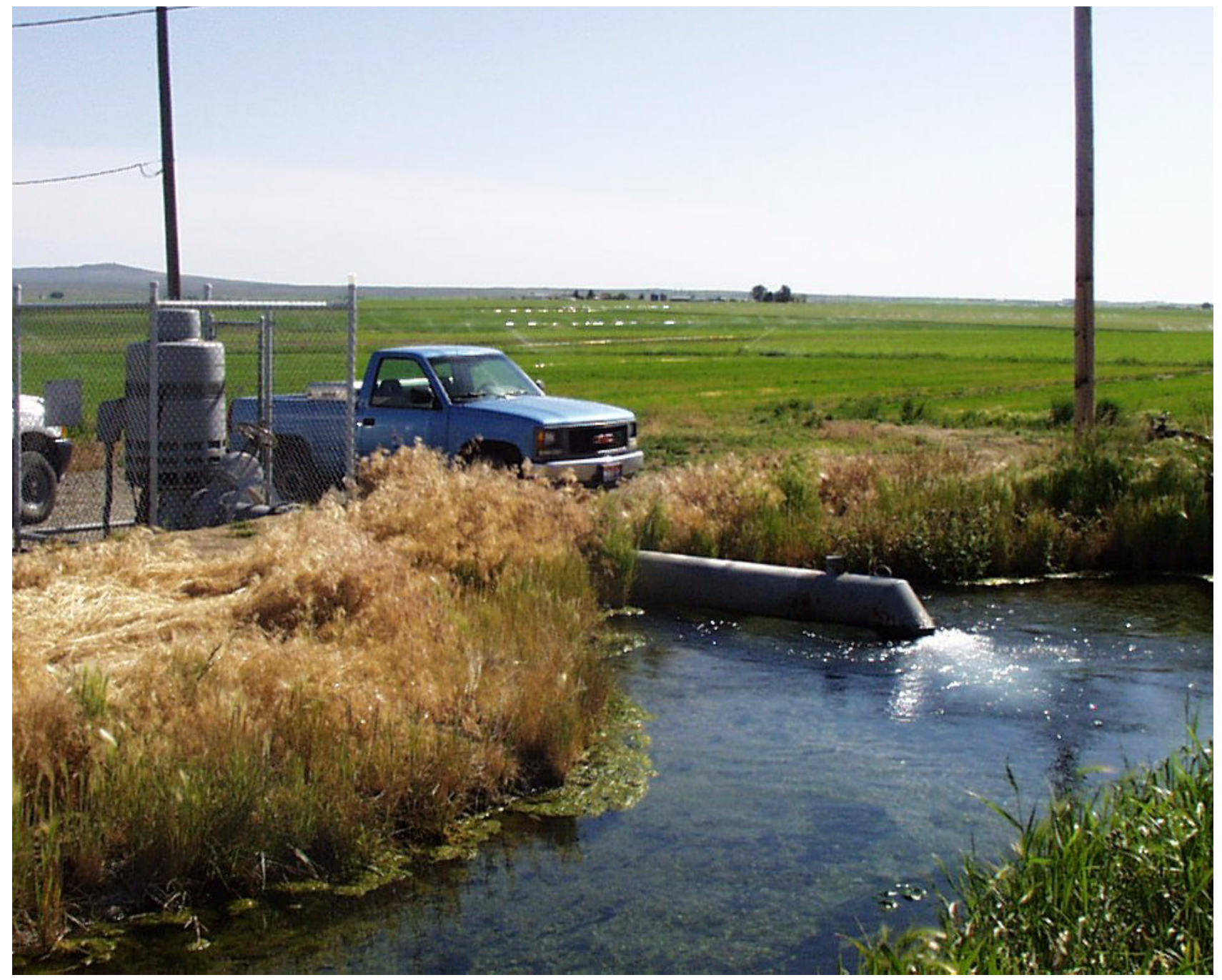

Open-File Report 2004-1004

U.S. Department of the Interior

U.S. Geological Survey 
Cover: Well discharge to a spilling pond on Snake River Plain. 
Radiochemical and Chemical Constituents in Water from Selected Wells and Springs from the Southern Boundary of the Idaho National Engineering and Environmental Laboratory to the Hagerman Area, Idaho, 2002

By Gordon W. Rattray, U.S. Geological Survey, and Linford J. Campbell, Idaho Department of Water Resources

U.S. GEOLOGICAL SURVEY

Open-File Report 2004-1004

Prepared in cooperation with the

U.S. DEPARTMENT OF ENERGY

and IDAHO DEPARTMENT OF WATER RESOURCES 


\section{U.S. DEPARTMENT OF THE INTERIOR}

GALE A. NORTON, Secretary

\section{U.S. GEOLOGICAL SURVEY}

CHARLES G. GROAT, Director

Any use of trade, product, or firm names in this publication is for descriptive purposes only and does not constitute endorsement by the U.S. Government.

Additional information can be obtained from:

U.S. Geological Survey

INEEL, MS 1160

P.O. Box 2230

Idaho Falls, ID 83403
Copies of this report can

be purchased from:

U.S. Geological Survey

Information Services

Box 25286, Federal Center

Denver, CO 80225
Copies of this report also are available in PDF format which can be viewed using Adobe Acrobat Reader at URL:

http://pubs.water.usgs.gov/ofr20041004/ 


\section{CONTENTS}

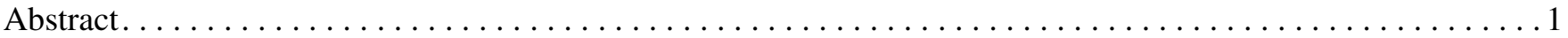

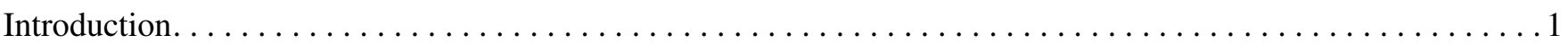

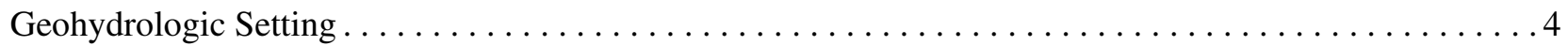

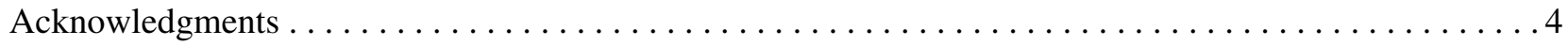

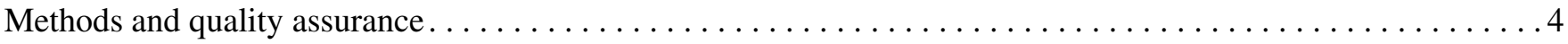

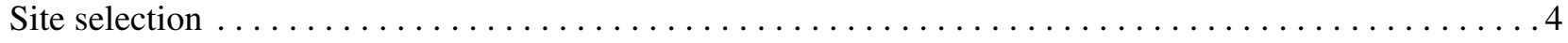

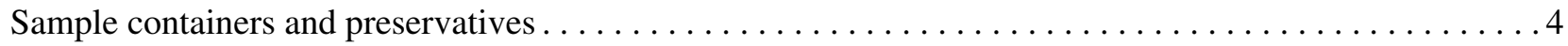

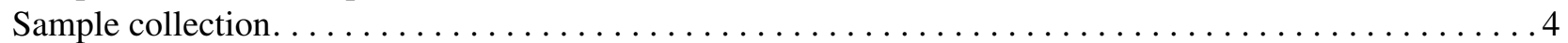

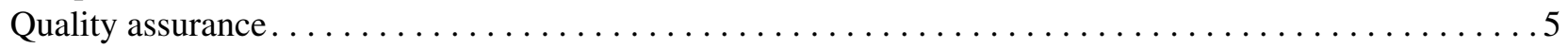

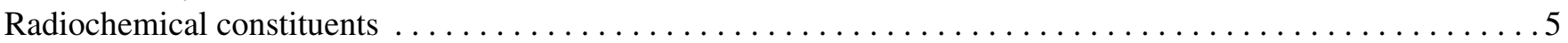

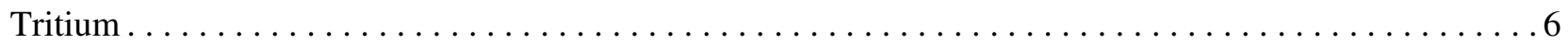

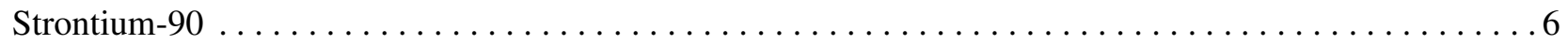

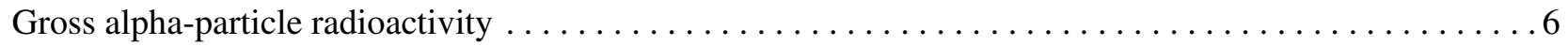

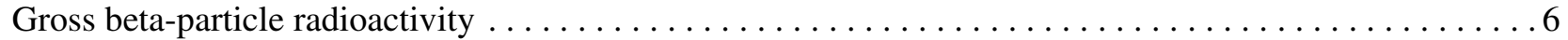

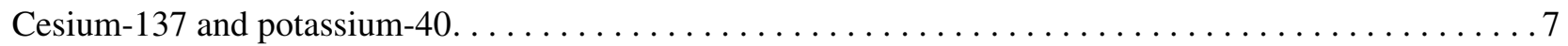

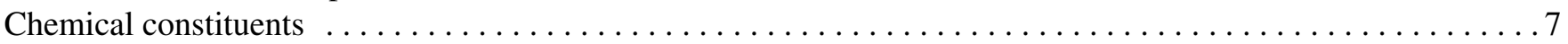

Trace elements . . . . .

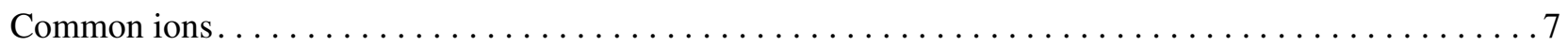

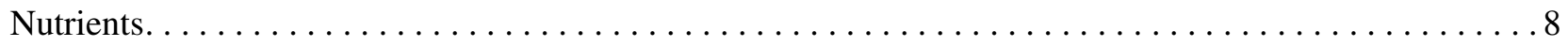

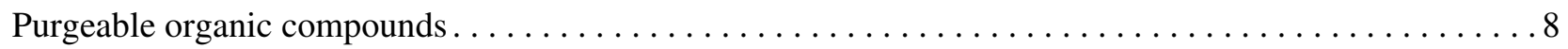

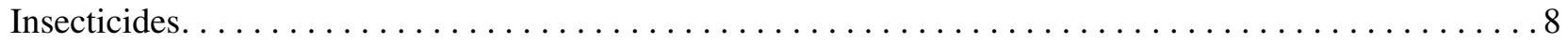

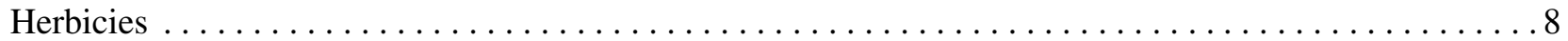

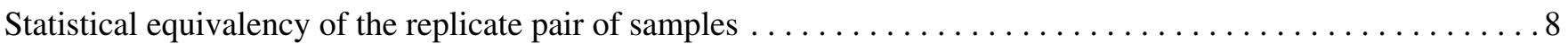

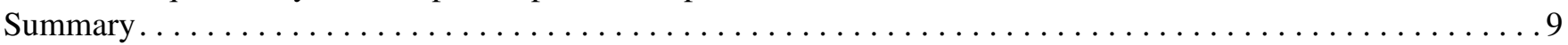

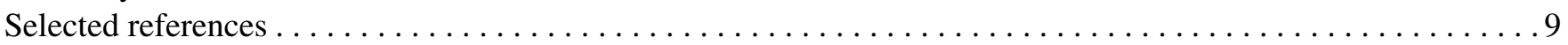

\section{FIGURES}

Figure 1. Location of the study area, between the Idaho National Engineering and Environmental Laboratory and

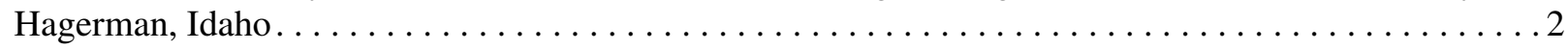

Figure 2. Location of selected water-quality sampling sites on the eastern Snake River Plain ............3

\section{TABLES}

Table 1. Containers and preservatives used for water-sample collection $\ldots \ldots \ldots \ldots \ldots \ldots \ldots \ldots \ldots \ldots$

Table 2. Results of field measurements of water for $\mathrm{pH}$, specific conductance, and temperature from selected

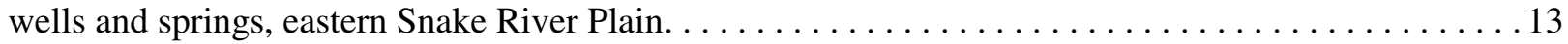

Table 3. Maximum contaminant levels for selected radionuclides and types of radioactivity in drinking water . . 14

Table 4. Concentrations of tritium and strontium-90 in water from selected wells and springs, eastern

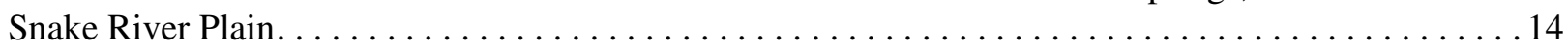

Table 5. Concentrations of gross alpha-particle and gross beta-particle radioactivity in water from selected

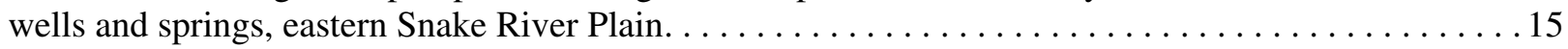

Table 6. Concentrations of cesium-137 and potassium-40 in water from selected wells and springs, eastern Snake River Plain. . . . . . . . . . . . . . . 16

Table 7. Maximum or secondary maximum contaminant levels and laboratory reporting levels of selected trace elements in drinking water. 
Table 8. Concentrations of dissolved trace elements in water from selected wells and springs, eastern Snake

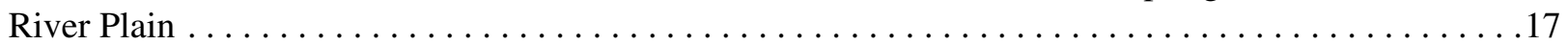

Table 9. Maximum contaminant levels and laboratory reporting levels of selected common ions and nutrients in

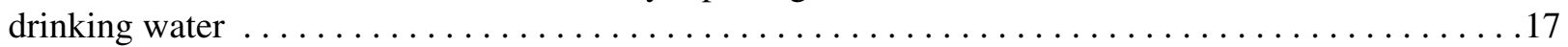

Table 10. Concentrations of dissolved common ions and nutrients in water from selected wells and springs,

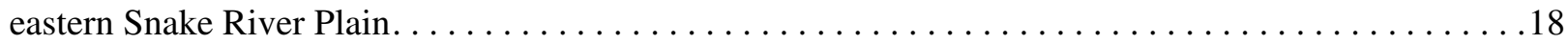

Table 11. Maximum contaminant levels and minimum reporting levels of selected purgeable organic

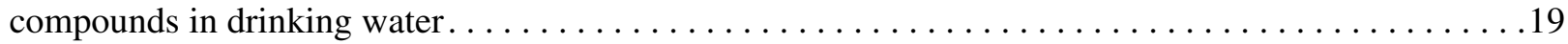

Table 12. Maximum contaminant levels, laboratory reporting levels, and long-term method detection levels

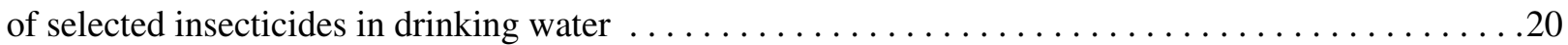

Table 13. Maximum contaminant levels, laboratory reporting levels, and long-term method detection levels

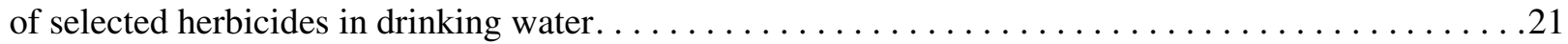

Table 14. Concentrations of selected herbicides in water from selected wells and springs, eastern Snake

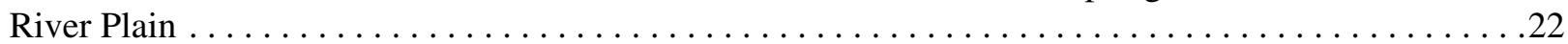

\section{CONVERSION FACTORS}

$\begin{array}{lcl}\text { Multiply } & \text { By } & \text { To Obtain } \\ \text { inch (in.) } & 25.4 & \text { millimeter }(\mathrm{mm}) \\ \text { foot }(\mathrm{ft}) & 0.3048 & \text { meter }(\mathrm{m}) \\ \text { mile }(\mathrm{mi}) & 1.609 & \text { kilometer }(\mathrm{km}) \\ \text { gallon }(\mathrm{gal}) & 3.785 & \text { liter } \\ \text { picocurie per liter }(\mathrm{pCi} / \mathrm{L}) & 0.037 & \text { becquerel per liter }(\mathrm{Bq} / \mathrm{L})\end{array}$

For temperature, degrees Celsius $\left({ }^{\circ} \mathrm{C}\right)$ may be converted to degrees Fahrenheit $\left({ }^{\circ} \mathrm{F}\right)$ by using the formula ${ }^{\circ} \mathrm{F}=(1.8)\left({ }^{\circ} \mathrm{C}\right)+32$.

Sea Level: in this report, "sea level" refers to the National Geodetic Vertical Datum of 1929, a geodetic datum derived from a general adjustment of the first-order level nets of the United States and Canada, formerly called "Sea Level Datum of 1929."

Abbreviated units used in report: $\mu \mathrm{S} / \mathrm{cm}$ (microsiemens per centimeter at $25^{\circ} \mathrm{C}$ ), $\mathrm{mg} / \mathrm{L}$ (milligrams per liter), $\mu \mathrm{g} / \mathrm{L}$ (micrograms per liter). 


\title{
Radiochemical and Chemical Constituents in Water from Selected Wells and Springs from the Southern Boundary of the Idaho National Engineering and Environmental Laboratory to the Hagerman Area, Idaho, 2002
}

\author{
By Gordon W. Rattray, U.S. Geological Survey, and Linford J. Campbell, Idaho Department of Water \\ Resources
}

\begin{abstract}
The U.S. Geological Survey, Idaho Department of Water Resources, and the State of Idaho INEEL Oversight Program, in cooperation with the U.S. Department of Energy, sampled water from 17 sites as part of the sixth round of a long-term project to monitor water quality of the eastern Snake River Plain aquifer from the southern boundary of the Idaho National Engineering and Environmental Laboratory to the Hagerman area. The samples were collected from eight irrigation wells, three domestic wells, one stock well, one dairy well, one commercial well, one observation well, and two springs and analyzed for selected radiochemical and chemical constituents. One quality-assurance sample, a sequential replicate, also was collected and analyzed.

Many of the radionuclide and inorganic-constituent concentrations were greater than the reporting levels and most of the organic-constituent concentrations were less than the reporting levels. However, none of the reported radiochemicalor chemical-constituent concentrations exceeded the maximum contaminant levels for drinking water established by the U.S. Environmental Protection Agency. Statistical evaluation of the replicate sample pair indicated that, with 95 percent confidence, 132 of the 135 constituent concentrations of the replicate pair were equivalent.
\end{abstract}

\section{INTRODUCTION}

The Idaho National Engineering and Environmental Laboratory (INEEL), a U.S. Department of Energy (DOE) facility, lies above the north-central part of the eastern Snake River Plain (ESRP) aquifer (fig. 1). Since the early 1950's, waste and wastewater from nuclear industrial processes have been disposed of and discharged to the subsurface at the INEEL. Until 1984, wastewater containing radiochemical and chemical wastes generated at the INEEL was discharged to both ponds and wells. Since 1984, however, most waste and wastewater has been discharged primarily to infiltration ponds (Pittman and others, 1988, p. 20). Currently, aqueous wastes are discharged to infiltration ponds or lined evaporation ponds, with such disposal carried out in accordance with appropriate wastewater discharge permits.

Ground water from the ESRP aquifer supplies southeastern Idaho with a large water supply for domestic and industrial uses. However, public concern about aqueous wastedisposal practices at the INEEL, and the effect of these practices on the water quality of the ESRP aquifer in areas downgradient from the INEEL, led the DOE to request that the U.S.

Geological Survey (USGS) conduct studies of the water quality of the aquifer between the southern boundary of the INEEL and the Minidoka-Twin Falls-Hagerman area (fig. 2). One study was a one-time sampling effort in the eastern part of the A \& B Irrigation District in Minidoka County (Mann and Knobel, 1990). Another study, discontinued after 2001, involved sampling for tritium from 19 springs on the north side of the Snake River in the Twin Falls-Hagerman area (Mann, 1989; Mann and Low, 1994; Twining, 2002). A third study, from which the results in this report are a part, is an ongoing annual sampling program between the southern boundary of the INEEL and the Minidoka-Twin Falls-Hagerman area. This study is being conducted by the USGS, the Idaho Department of Water Resources, and the State of Idaho INEEL Oversight Program (INEEL OP) in cooperation with the DOE.

The initial round of sampling for the third study involved analyzing water samples collected from 55 sites during August and September 1989 (Wegner and Campbell, 1991). Subsequent rounds of sampling have involved collecting and analyzing water samples annually from about one-third of the sites. This sampling format ensures that all of the sites are sampled over a 3-year period. In 2002, for budgetary reasons, the total number of sampling sites was reduced to 46 . Because water-quality results from eliminated sites generally were similar to those of nearby sites preserved in the sampling program, the impact on overall water-quality information is 


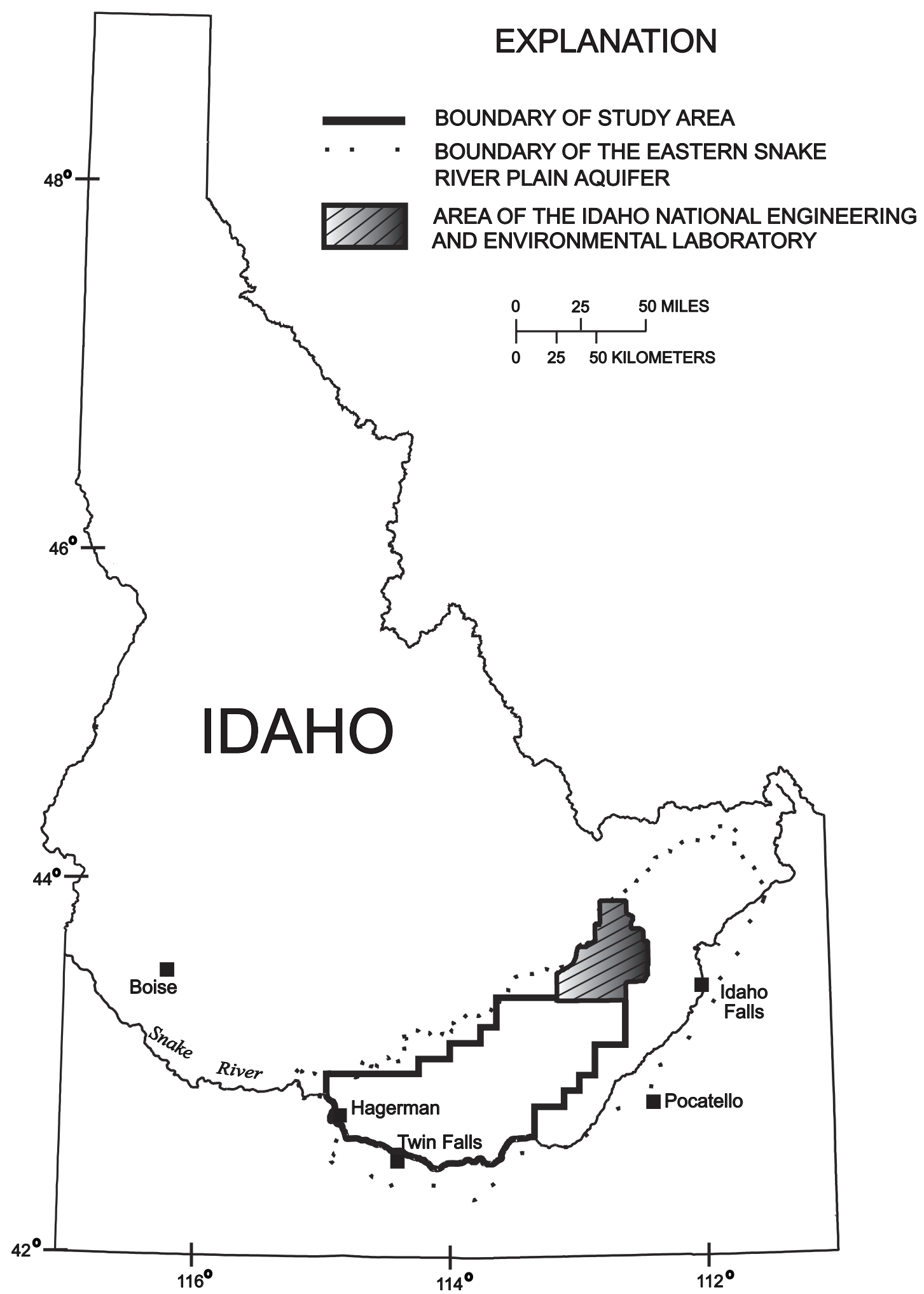

Figure 1. Location of the study area, between the Idaho National Engineering and Environmental Laboratory and Hagerman, Idaho. 


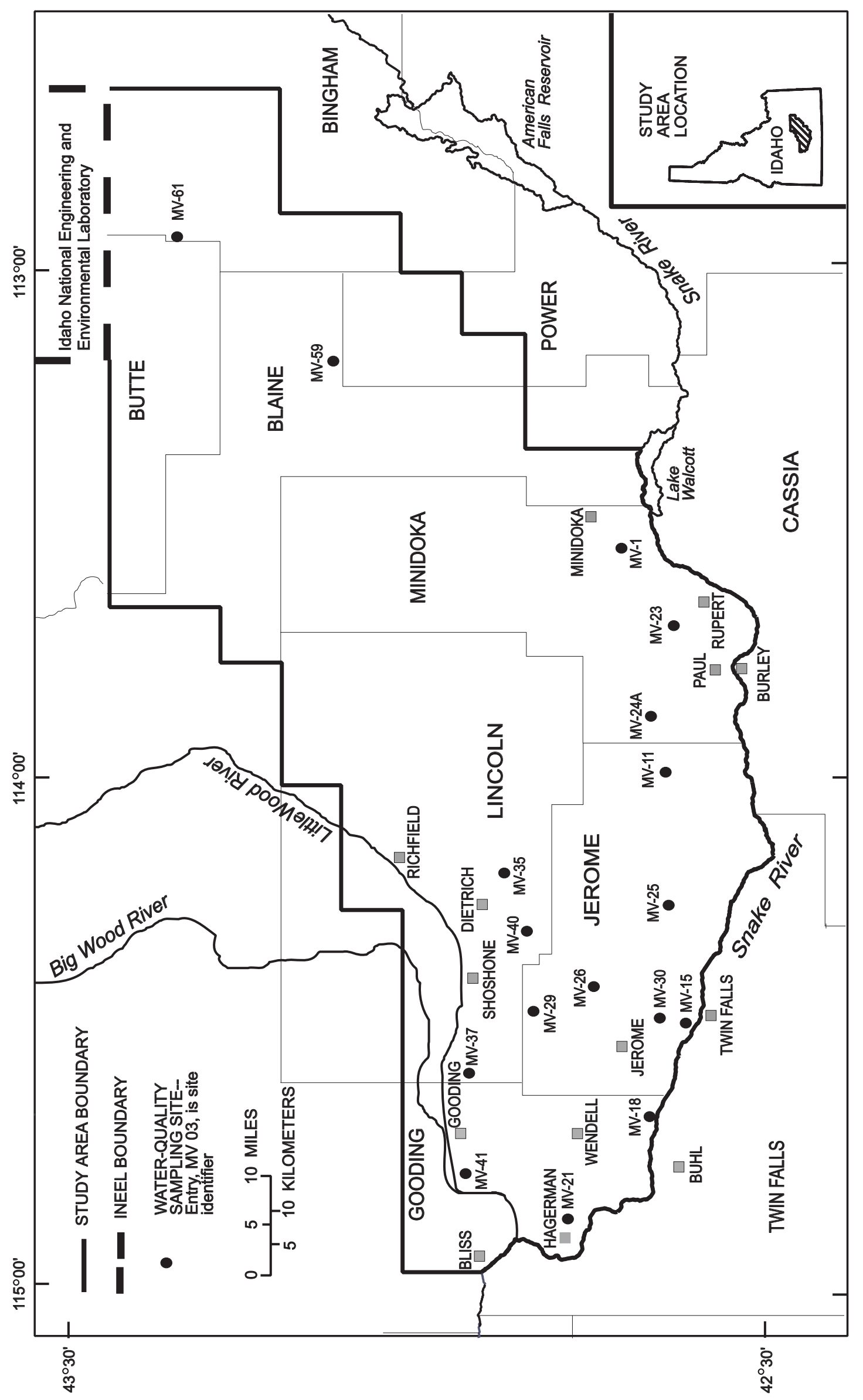

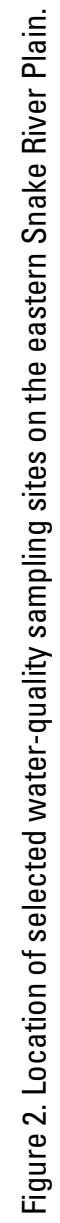




\section{Radiochemical and Chemical Constituents in Water from Selected Wells and Springs}

expected to be negligible. Data for a variety of radiochemical and chemical constituents from the sampling rounds have been published in reports by Bartholomay, Edwards, and Campbell (1992, 1993, 1994a, 1994b); Bartholomay, Williams, and Campbell (1995, 1996, 1997b, 1998); Bartholomay, Twining, and Campbell (1999, 2000, 2001); and Twining, Rattray, and Campbell (2003). An evaluation of the results from this study from 1989 through 1992 was published by Bartholomay, Williams, and Campbell (1997a).

Water samples collected by the USGS from 17 sites in 2002 (fig. 2) were analyzed by the USGS National Water Quality Laboratory (NWQL) for radionuclides, trace elements, common ions, nutrients, purgeable organic compounds, insecticides, and herbicides. Water samples were also collected by the INEEL OP and sent to the Environmental Monitoring Laboratory at Idaho State University (ISU-EML) for radionuclide analyses. One quality-assurance (QA) sample, a sequential replicate, also was collected and analyzed.

\section{Geohydrologic Setting}

The ESRP is a northeast-trending structural basin about $200 \mathrm{mi}$ long and 50 to $70 \mathrm{mi}$ wide. The basin, bounded by faults on the northwest and downwarping and faulting on the southeast, has been filled with basaltic lava flows interbedded with terrestrial sediments (Whitehead, 1986). Thickness of individual basalt flows averages 20 to $25 \mathrm{ft}$, and aggregate thickness is as much as several thousand feet in places. Alluvial fan deposits are composed primarily of sand and gravel whereas, in areas where streams were dammed by basalt flows, the sediments are predominantly silt and clay (Garabedian, 1986). Rhyolitic lava rocks and tuffs are exposed locally at the surface and may exist at depth under most of the eastern plain. A 10,365-ft-deep test hole at the INEEL penetrated about 2,160 ft of basalt and sediment and 8,205 ft of tuffaceous and rhyolitic volcanic rocks (Mann, 1986).

The ESRP aquifer is recharged by seepage from the upper reaches of the Snake River, tributaries and canals, infiltration from irrigation and precipitation, and underflow from tributary valleys on the perimeter of the plain. Discharge from the aquifer is primarily by pumpage for irrigation and spring flow to the Snake River (Mann and Knobel, 1990). Discharge from springs in the ESRP has fluctuated during the nearly 100 years of flow monitoring as a result of changes in water use, irrigation practices, and precipitation (Kjelstrom, 1992, p. 2).

Movement of water in the aquifer generally is from the northeast to southwest. Water moves horizontally through basalt interflow zones and vertically through joints and interfingering edges of the interflow zones. Infiltration of surface water, heavy pumpage, geologic conditions, and seasonal fluxes of recharge and discharge locally affect the movement of ground water (Garabedian, 1986).

\section{Acknowledgments}

The authors thank the well owners for granting permission to collect the water samples. The authors are grateful for technical review of the manuscript by Flint Hall of the INEEL OP and LeRoy L. Knobel of the USGS.

\section{METHODS AND QUALITY ASSURANCE}

The methods used in sampling and analyzing for selected chemicals generally followed the guidelines established by the USGS (Goerlitz and Brown, 1972; Stevens and others, 1975; Wood, 1981; Claassen, 1982; W.L. Bradford, USGS, written commun., 1985; Wershaw and others, 1987; Fishman and Friedman, 1989; Faires, 1992; Fishman, 1993; Zaugg and others, 1995; and Wilde and others, 1998, 1999, 2002). The methods used in the field and QA practices are described in the following sections.

\section{Site Selection}

Water samples were collected at 17 sites (fig. 2). The sites include eight irrigation wells, three domestic wells, one stock well, one dairy well, one commercial well, one observation well, and two springs. Criteria for site selection were geographic location, ease of sample collection, and long-term access.

\section{Sample Containers and Preservatives}

Sample containers and preservatives differ depending on the constituent(s) to be analyzed. Water samples analyzed by the NWQL were collected and preserved in accordance with laboratory requirements specified by Timme (1995). Water samples analyzed by ISU-EML were collected in accordance with the INEEL OP sample collection procedures. Sample containers, preservatives, and other treatments are summarized in table 1 .

\section{Sample Collection}

Most irrigation wells were sampled from spigots in discharge lines, but some were sampled from stilling ponds at the pump discharge point. A peristaltic pump was used to transfer water from the stilling pond to sample bottles. Domestic, stock, dairy, and commercial wells were sampled from spigots closest to the pumps. The observation well was sampled from a 1/4-in. sample port connected to the discharge line. All the wells either were pumping on arrival of the sampling team or were started on arrival and pumped long 
enough to ensure that pressure tanks and pumping systems had been thoroughly flushed as evidenced by stable $\mathrm{pH}$, specific conductance, and water-temperature measurements. The springs were sampled as near the source as possible, and a peristaltic pump was used to fill the sample bottles with water from the springs.

Chemical and physical characteristics monitored at the sample-collection sites included $\mathrm{pH}$, specific conductance, and water temperature. These characteristics were monitored during pumping using methods described by Wood (1981) and Hardy and others (1989). A water sample was collected after measurements of these characteristics indicated probable physical and chemical stability. After collection, sample containers were sealed with laboratory film, labeled, and packed into ice chests for shipment to the NWQL. The samples collected for ISU-EML were stored until they were handdelivered to the laboratory.

The sites sampled, site types, sample collection dates, and field measurements of $\mathrm{pH}$, specific conductance, and water temperature are shown in table 2 . These measurements ranged from 7.4 to 8.3 for $\mathrm{pH}$, from 286 to $1,009 \mu \mathrm{S} / \mathrm{cm}$ for specific conductance, and from 13.6 to $16.5^{\circ} \mathrm{C}$ for water temperature.

Conditions at the sampling site during sample collection were recorded in a field logbook and a chain-of-custody record was used to track the samples from the time of collection until delivery to the analyzing laboratory. These records are available for inspection at the USGS INEEL Project Office. Records for samples analyzed by ISU-EML are maintained at the ISU laboratory.

\section{Quality Assurance}

Internal quality control and overall QA practices used by the NWQL are described in reports by Friedman and Erdmann (1982), Jones (1987), and Pritt and Raese (1995). Water samples analyzed by the NWQL were collected and handled in accordance with a QA plan for quality-of-water activities conducted by personnel at the INEEL Project Office. The plan was finalized in June 1989, revised in 1992 and 1996 (Mann, 1996), and is available for inspection at the USGS INEEL

Project Office. Water samples analyzed by the ISU-EML were collected and handled in accordance with procedures described by Hall (2002).

Approximately 10 percent of the water samples collected in this sampling program were QA samples. An evaluation of QA results, for samples collected between 1989 through 1995, was presented by Williams and others (1998). In 2002, one QA sample was collected (MV-8, which is a sequential replicate of MV-1). An evaluation of the statistical equivalency of this replicate sample pair is presented below. In addition, the INEEL OP has published a statistical comparison of analytical results from duplicate water samples collected by the USGS and the INEEL OP (INEEL OP, 2003).

\section{RADIOCHEMICAL CONSTITUENTS}

Water samples were analyzed for tritium, strontium-90, gross alpha-particle and gross beta-particle radioactivity, and the gamma-emitting radionuclides cesium-137 and potassium-40. The samples were analyzed using methods described by Thatcher and others (1977). The U.S. Environmental Protection Agency (EPA) maximum contaminant levels (MCL's) for selected radionuclides and for types of radioactivity in drinking water are listed in table 3.

An analytical uncertainty, $\mathbf{s}$, is calculated by the analyzing laboratory for each radionuclide concentration or radioactivity measurement. This report presents the analytical uncertainty as 2s. Guidelines for interpreting analytical results are based on an extension of the method described by Currie (1984). In radiochemical analyses, laboratory measurements are made on a target sample and a prepared blank. Instrument signals for the sample and blank vary randomly. Therefore, it is essential to distinguish between two key aspects of the problem of detection: (1) the instrument signal for the sample must be greater than the signal for the blank to make the decision that there was detection; and (2) an estimation must be made of the minimum concentration that will yield a sufficiently large signal to make the correct decision for detection or nondetection most of the time. The first aspect of the problem is a qualitative decision based on signals and a definite criterion for detection. The second aspect of the problem is an estimation of the detection capabilities of a complete measurement process that includes hypothesis testing.

For radionuclide analyses in this sampling program, the critical level for detection of a constituent is defined as 1.6s. A radionuclide concentration or radioactivity measurement that is above this critical level is determined as being detected in the sample. Given a large number of samples, as many as 5 percent of the samples with measured concentrations equal to or greater than $1.6 \mathbf{s}$, which were determined as containing the radionuclide or radioactivity, might not contain the radioactive constituent. These measurements are referred to as false positives and are errors of the first type in hypothesis testing.

A concentration that equals $3 \mathrm{~s}$ represents a measurement at the minimum detectable concentration. For samples containing a true concentration of $3 \mathbf{s}$ or greater, there is a 95-percent-ormore probability that the radioactive constituent will be determined as being present in the sample. Given a large number of samples, as many as 5 percent of the samples with true concentrations greater than or equal to $3 \mathbf{s}$ could be determined as not containing the radionuclide or radioactivity. These measurements are referred to as false negatives and are errors of the second type in hypothesis testing.

More false negative than false positive measurements are made on samples containing true radionuclide concentrations between $1.6 \mathrm{~s}$ and $3 \mathrm{~s}$, and there is a greater-than-5-percent 


\section{Radiochemical and Chemical Constituents in Water from Selected Wells and Springs}

probability of false negative results for these samples. At 1.6s, the probability of a false negative is about 50 percent.

These guidelines are based on counting statistics alone and do not include systematic or random errors inherent in laboratory procedures. The values $1.6 \mathrm{~s}$ and $3 \mathrm{~s}$ vary slightly with background or blank counts and with the number of gross counts for individual analyses. The use of the critical level and minimum detectable concentration aids the reader in the interpretation of analytical results and does not represent absolute concentrations of radioactivity that may or may not have been detected. In this report, if the concentration of a selected radionuclide was equal to or greater than $3 \mathbf{s}$, the concentration is considered to be above a "reporting level." The reporting level should not be confused with the analytical method detection limit, which is based on laboratory procedures. At small concentrations, the reporting level approaches the analytical method detection limit; however, at larger concentrations, they may be significantly different.

Many analytical results of environmental radioactivity measurements are at or near zero. If the true concentration for a given radionuclide is zero, a given set of analytical results for that radionuclide should be distributed about zero, with an equal number of negative and positive measurements. Negative analytical results occur if the radioactivity measured in a water sample is less than the radioactivity measured in a background or blank sample (American Society for Testing and Materials, 1992, p. 126; Knobel and others, 1992, p. 51).

\section{Tritium}

Tritium, a radioactive isotope of hydrogen, is formed in nature by interactions of cosmic rays with gases in the upper atmosphere. Tritium also is produced in thermonuclear detonations and is a waste product of nuclear industrial processes. At the INEEL, discharge of industrial wastewater resulted in tritium concentrations in the aquifer by 1961 that exceeded the 20,000 pCi/L MCL for tritium (Mann and Cecil, 1990). Since 1961 tritium concentrations in the aquifer have generally decreased (Mann and Cecil, 1990) and by 1998 tritium concentrations in all aquifer samples from the INEEL were less than the MCL (Bartholomay, Tucker, Davis, and Greene, 2000). However, while concentrations of tritium were decreasing the areal distribution of tritium in the aquifer was increasing, and by 1983 tritium was detected in water from wells along the southern boundary of the INEEL, 8 to 9 miles south of the discharge location (Pittman and others, 1988). This corresponds to an apparent transport velocity for tritium of 4 to 5 feet per day.

Ground-water samples collected in the study area in 2002 for tritium analysis were submitted to the NWQL and the ISU-EML, laboratories located in Lakewood, CO, and Pocatello, ID, respectively. The NWQL and ISU-EML both use an electrolytic enrichment liquid-scintillation counting method; in addition, the ISU-EML performs a second set of analyses using a standard liquid-scintillation counting method. The analytical method detection limit for the NWQL was $1 \mathrm{pCi} / \mathrm{L}$ for a 1,000-minute counting period; for the ISU-EML the analytical method detection limits were $150 \mathrm{pCi} / \mathrm{L}$ (standard method) and less than $25 \mathrm{pCi} / \mathrm{L}$ (enrichment method) for 200-minute counting periods.

Concentrations of tritium in water samples analyzed by the NWQL ranged from $-0.3 \pm 1.0$ to $47.7 \pm 3.2 \mathrm{pCi} / \mathrm{L} ; 16$ of the concentrations exceeded the reporting level (table 4). Concentrations of tritium in water samples analyzed by the ISU-EML using the enrichment method ranged from $2 \pm 6$ to $44 \pm 7 \mathrm{pCi} / \mathrm{L} ; 15$ of the concentrations exceeded the reporting level (table 4). Background concentrations of tritium in ground water in Idaho generally range from 0 to $40 \mathrm{pCi} / \mathrm{L}$ (Knobel and others, 1992).

\section{Strontium-90}

Strontium-90 is a fission product that was widely distributed in the environment during atmospheric weapons tests. Strontium-90 generally is present in ground water as a result of these tests and from nuclear industry waste-disposal practices. Because strontium-90 sorbs onto sediment material in the aquifer it is not expected to move past its current location at the INEEL (Bartholomay, 1998). Concentrations of dissolved strontium-90 in all of the water samples were less than the reporting level and ranged from $-0.033 \pm 0.17$ to $0.223 \pm 0.34 \mathrm{pCi} / \mathrm{L}$ (table 4 ).

\section{Gross Alpha-Particle Radioactivity}

Gross alpha-particle radioactivity is a measure of the total radioactivity given off as alpha particles during the radioactive decay process; however, laboratories normally report the radioactivity as if it were all given off by one radionuclide. In this report, concentrations in $\mathrm{pCi} / \mathrm{L}$ are reported as dissolved thorium-230 by the NWQL and as total thorium-230 by the ISU-EML.

The concentration of gross alpha-particle radioactivity in water samples analyzed by the NWQL ranged from $0.95 \pm 1.88$ to $7.27 \pm 3.93 \mathrm{pCi} / \mathrm{L}$; two of the concentrations were greater than the reporting level (table 5). Concentrations of gross alphaparticle radioactivity in water samples analyzed by the ISU-EML ranged from $-0.9 \pm 2.2$ to $5.2 \pm 2.2 \mathrm{pCi} / \mathrm{L}$; six of the concentrations were greater than the reporting level (table 5). The largest concentration, $7.27 \pm 3.93 \mathrm{pCi} / \mathrm{L}$, was below the 15 $\mathrm{pCi} / \mathrm{L} \mathrm{MCL}$ for gross alpha-particle radioactivity (table 3 ).

\section{Gross Beta-Particle Radioactivity}

Gross beta-particle radioactivity is a measure of the total radioactivity given off as beta particles during the radioactive decay process. Laboratories normally report this radioactivity as if it were all given off by one radionuclide. In this report, concentrations in $\mathrm{pCi} / \mathrm{L}$ are reported as dissolved cesium-137 
by the NWQL and as total cesium-137 by the ISU-EML. The MCL for gross beta-particle and gamma radioactivity is $4 \mathrm{mrem} / \mathrm{yr}$ (table 3). (The average annual concentrations of tritium and strontium-90 in public drinking-water supplies that produce a $4-\mathrm{mrem} / \mathrm{yr}$ dose are 20,000 and $8 \mathrm{pCi} / \mathrm{L}$, respectively (table 3 ). Gross beta-particle radioactivity measurements should not be compared directly with these concentrations).

Concentrations of gross beta-particle radioactivity in all of the water samples analyzed by the NWQL were greater than the reporting level (table 5) and ranged from $3.65 \pm 1.17$ to $12.29 \pm 3.96 \mathrm{pCi} / \mathrm{L}$. Concentrations of gross beta-particle radioactivity in water samples analyzed by the ISU-EML ranged from $1.1 \pm 0.8$ to $5.5 \pm 1.0 \mathrm{pCi} / \mathrm{L} ; 17$ of the concentrations were greater than the reporting level (table 5).

\section{Cesium-137 and Potassium-40}

Concentrations of cesium- 137 and potassium- 40 in the water samples were determined with gamma spectrometry. Cesium-137 is a fission product of uranium-235, uranium-233, or plutonium-239. Potassium makes up approximately 2.6 percent of the Earth's continental crust, and 0.0118 percent of all potassium is the naturally occurring radioactive isotope potassium-40 (Eisenbud and Gesell, 1997).

Concentrations of cesium-137 in water samples ranged from $-0.8 \pm 2.0$ to $2.9 \pm 2.1 \mathrm{pCi} / \mathrm{L}$; all of the concentrations were less than the reporting level (table 6). The concentrations of potassium-40 in water samples ranged from $-27 \pm 53$ to $81 \pm 44 \mathrm{pCi} / \mathrm{L}$; four of the concentrations were greater than the reporting level (table 6).

\section{CHEMICAL CONSTITUENTS}

Chemical constituents analyzed from the water samples included trace elements, common ions, nutrients, purgeable organic compounds, insecticides, and herbicides. For chemical constituents, minimum reporting levels (MRL's), laboratory reporting levels (LRL's), and long-term method detection limits (LT-MDL's) are used to determine when a chemical constituent has been detected with sufficient confidence.

The MRL is the smallest measured concentration of a constituent that may be reliably reported using a given analytical method (Timme, 1995). In this report, MRL's are used only with purgeable organic compounds. The LRL is determined such that "the probability of falsely reporting a non-detection for a sample that contained an analyte at a concentration equal to or greater than the LRL is predicted to be less than or equal to 1 percent" (Childress and others, 1999, p. 19). This is known as a false negative and is an error of the second type in hypothesis testing. The LT-MDL is determined by calculating the standard deviation of a large sample population (at least 24 measurements) of spiked sample measurements over an extended period of time (often one year).
The probability "of falsely reporting a concentration at or greater than the LT-MDL for a sample that did not contain the analyte is predicted to be less than or equal to 1 percent" (Childress and others, 1999, p. 19). This is known as a false positive and is an error of the first type in hypothesis testing.

\section{Trace Elements}

Water samples were analyzed for selected dissolved trace elements including barium, chromium, iron, lead, lithium, manganese, mercury, strontium, and zinc. The maximum or secondary MCL's and LRL's for these trace elements are shown in table 7 and the measured concentrations are shown in table 8.

Barium: Concentrations of barium ranged from 10 to $137 \mu \mathrm{g} / \mathrm{L}$. All of these concentrations were greater than the LRL of $0.9 \mu \mathrm{g} / \mathrm{L}$. The MCL for barium is $2,000 \mu \mathrm{g} / \mathrm{L}$.

Chromium: The concentration of chromium in all samples was greater than, equal to, or estimated to be slightly less than the LRL of $0.8 \mu \mathrm{g} / \mathrm{L}$. Concentrations ranged from an estimated 0.6 to $4.1 \mu \mathrm{g} / \mathrm{L}$. The MCL for chromium is $100 \mu \mathrm{g} / \mathrm{L}$.

Iron: Concentrations of iron in 16 of the 18 samples were less than the LRL of $10 \mu \mathrm{g} / \mathrm{L}$. The two concentrations that exceeded the LRL were estimated at 5.7 and $8.7 \mu \mathrm{g} / \mathrm{L}$. The secondary MCL for iron is $300 \mu \mathrm{g} / \mathrm{L}$.

Lead: Concentrations of lead in seven samples ranged from an estimated 0.6 to $1.3 \mu \mathrm{g} / \mathrm{L}$. Three of these concentrations exceeded the LRL of $1 \mu \mathrm{g} /$; all other sample concentrations were less than the LRL. Lead has an EPA action level of $15 \mu \mathrm{g} / \mathrm{L}$.

Lithium: Concentrations of lithium in all samples were greater than the LRL of $3.9 \mu \mathrm{g} / \mathrm{L}$. The concentrations ranged from 6 to $46 \mu \mathrm{g} / \mathrm{L}$. No MCL for lithium has been established.

Manganese: The concentration of manganese in one sample was estimated at $0.8 \mu \mathrm{g} / \mathrm{L}$. Concentrations in all other samples were reported as less than the LRL of $2 \mu \mathrm{g} / \mathrm{L}$. The secondary MCL for manganese is $50 \mu \mathrm{g} / \mathrm{L}$.

Mercury: The concentrations of mercury in all samples were less than the LRL of $0.011 \mu \mathrm{g} / \mathrm{L}$. The MCL for mercury is $2 \mu \mathrm{g} / \mathrm{L}$.

Strontium: Concentrations of strontium in all samples were greater than the LRL of $0.6 \mu \mathrm{g} / \mathrm{L}$ and ranged from 120 to $429 \mu \mathrm{g} / \mathrm{L}$. No MCL for strontium has been established.

Zinc: Concentrations of zinc in seven samples ranged from an estimated 16 to $238 \mu \mathrm{g} / \mathrm{L}$. All other concentrations were less than the LRL for zinc of $24 \mu \mathrm{g} / \mathrm{L}$. The secondary MCL for zinc is $5,000 \mu \mathrm{g} / \mathrm{L}$.

\section{Common Ions}

Water samples were analyzed for dissolved common ions including calcium, magnesium, silica, and sodium. The LRL's for these ions are shown in table 9. No MCL's have been 


\section{Radiochemical and Chemical Constituents in Water from Selected Wells and Springs}

established for these ions. The concentrations of dissolved common ions are shown in table 10.

Calcium: Concentrations of calcium in all samples were greater than the LRL of $0.012 \mathrm{mg} / \mathrm{L}$ and ranged from 25 to $78 \mathrm{mg} / \mathrm{L}$.

Magnesium: Concentrations of magnesium in all samples were greater than the LRL of $0.008 \mathrm{mg} / \mathrm{L}$ and ranged from 12 to $32 \mathrm{mg} / \mathrm{L}$.

Silica: Concentrations of silica in all samples were greater than the LRL of $0.13 \mathrm{mg} / \mathrm{L}$ and ranged from 30 to $42 \mathrm{mg} / \mathrm{L}$.

Sodium: Concentrations of sodium in all samples were greater than the LRL of $0.09 \mathrm{mg} / \mathrm{L}$ and ranged from 12 to $80 \mathrm{mg} / \mathrm{L}$.

\section{Nutrients}

Water samples were analyzed for dissolved ammonia (as nitrogen), nitrite (as nitrogen), nitrite plus nitrate (as nitrogen), and orthophosphate (as phosphorus). The MCL's and the LRL's are shown in table 9. Concentrations of nutrients are shown in table 10.

Ammonia (as nitrogen): Concentrations of ammonia (as nitrogen) in all samples were reported as less than 0.04 and were less than the laboratory reporting level of $0.041 \mathrm{mg} / \mathrm{L}$.

Nitrite (as nitrogen): Concentrations of nitrite (as nitrogen) in all samples were less than the LRL of $0.008 \mathrm{mg} / \mathrm{L}$. The maximum contaminant level is $1 \mathrm{mg} / \mathrm{L}$.

Nitrite plus nitrate (as nitrogen): Concentrations of nitrite plus nitrate (as nitrogen) in all samples were greater than the LRL of $0.047 \mathrm{mg} / \mathrm{L}$ and ranged from 0.5 to $7.8 \mathrm{mg} / \mathrm{L}$. The MCL is $10 \mathrm{mg} / \mathrm{L}$.

Orthophosphate (as phosphorus): Concentrations of orthophosphate (as phosphorus) ranged from an estimated 0.009 to $0.074 \mathrm{mg} / \mathrm{L}$. Seven of these concentrations exceeded the LRL for orthophosphate of $0.018 \mathrm{mg} / \mathrm{L}$.

\section{Purgeable Organic Compounds}

Water samples were analyzed for concentrations of 61 purgeable organic compounds. The MCL's and MRL's of these compounds are shown in table 11. Concentrations of trichloromethane were $0.2276,1.527$, and $0.3126 \mu \mathrm{g} / \mathrm{L}$ in water samples from wells MV-24A, MV-26, and MV-30, respectively. The concentration of bromodichloromethane in water from well MV-26 was $0.2944 \mu \mathrm{g} / \mathrm{L}$. All samples had a total trihalomethane (thm) concentration that was less than the MCL for thm of $100 \mu \mathrm{g} / \mathrm{L}$. All other concentrations of purgeable organic compounds in the water samples were less than the indicated MRL's.

\section{Insecticides}

Water samples were analyzed for concentrations of 19 insecticides. The MCL's, LRL's, and LT-MDL's for these compounds are shown in table 12. Concentrations of insecticides in all samples were less than the indicated LRL's.

\section{Herbicides}

Water samples were analyzed for concentrations of 28 herbicides. The MCL's, LRL's, and LT-MDL's for these compounds are shown in table 13. Estimated and reported concentrations ranged from 0.0031 to $0.0206 \mu \mathrm{g} / \mathrm{L}$ for atrazine, 0.0026 to $0.0195 \mu \mathrm{g} / \mathrm{L}$ for deethyl atrazine, and 0.0029 to $0.0155 \mu \mathrm{g} / \mathrm{L}$ for simazine. One estimated value of $0.0038 \mu \mathrm{g} / \mathrm{L}$ for metolachlor was reported; all other values of metolachlor were less than the LRL (table 14). These estimated and reported concentrations were all less than the indicated MCL's. All other concentrations of herbicides in the water samples were less than the indicated LRL's.

\section{STATISTICAL EQUIVALENCY OF THE REPLICATE PAIR OF SAMPLES}

A determination of the statistical equivalency of concentrations of chemical constituents in the replicate sample pair was performed following the method outlined by Williams (1996). With this method concentrations of the replicate pair were determined for their statistical equivalence within a specified confidence level. The determination of equivalency was performed by determining the standard deviate, Z. After the $\mathrm{Z}$-value was calculated, the level of significance of the result was evaluated (calculation of the level of significance assumes that the sample population is distributed normally). For this report concentrations from replicate samples are considered equivalent if the results are within two standard deviations of each other. At this confidence level (95-percent) the level of significance, determined from a standard normal probability curve, is 0.05 for a two-tailed test and corresponds to a $\mathrm{Z}$-value of 1.96 .

The equation used to determine $\mathrm{Z}$ was adapted from Volk (1969), where:

$$
Z=\frac{|x-y|}{\sqrt{\left(S_{x}\right)^{2}+\left(S_{y}\right)^{2}}}
$$

where

$x$ is the result of the routine water-quality sample,

$y$ is the result of the sequential replicate sample,

$S_{x}$ is the standard deviation of $x$, and

$S_{y}$ is the standard deviation of $\mathrm{y}$.

The standard deviations used in equation 1 were calculated by the analyzing laboratory for radionuclides and approximated from NWQL-determined most probable deviations for inorganic constituents (Ted Struzeski, personal commun., NWQL, 2003) and relative standard deviations for organic constituents (Donna Rose, volatile organic compounds; Jim Madsen, pesticides; personal communs., NWQL, 2003). 
Constituent concentrations in the replicate pair were considered statistically equivalent when the calculated Z-value was less than or equal to 1.96. Constituent concentrations were also considered statistically equivalent, although Z-values were not calculated, when the concentration of both samples was reported as less than the LRL or MRL or when one sample had a concentration reported as less than the LRL and the other sample had an estimated concentration that was less than the LRL (a result may be estimated for a variety of laboratoryspecific reasons; for instance, the result may lie outside the calibrated range of the instrument; estimated results have increased uncertainty (Childress and others, 1999, p. 8-10)). The constituent concentrations of the replicate samples analyzed by the NWQL, with the exception of orthophosphorous, were all statistically equivalent. The Z-value for orthophosphorous was 3.54 (one estimated concentration was used to calculate this value, however). The constituent concentrations of the replicate samples analyzed by the ISU-EML were considered statistically equivalent for tritium, cesium-137 and potassium-40. Concentrations for both gross alpha-particle and gross beta-particle radioactivity, however, had Z-values of 4.24 and 4.01, respectively, and were not equivalent. Of the 135 constituents analyzed from the replicate sample pair, statistical comparison indicates that 132 of the concentration pairs were equivalent.

\section{SUMMARY}

The U.S. Geological Survey, Idaho Department of Water Resources, and the State of Idaho INEEL Oversight Program, in cooperation with the Department of Energy, sampled water from 17 sites as part of the sixth round of a long-term project to monitor water quality of the eastern Snake River Plain aquifer from the southern boundary of the Idaho National Engineering and Environmental Laboratory to the Hagerman area. The samples were collected from eight irrigation wells, three domestic wells, one stock well, one dairy well, one commercial well, one observation well, and two springs. One qualityassurance sample also was collected. Water samples were analyzed for selected radiochemical and chemical constituents.

Concentrations of radionuclides in water samples ranged from $-0.3 \pm 1.0$ to $47.7 \pm 3.2 \mathrm{pCi} / \mathrm{L}$ for tritium (electrolytic enrichment technique), $-0.0337 \pm 0.17$ to $0.223 \pm 0.34 \mathrm{pCi} / \mathrm{L}$ for strontium-90, $-0.9 \pm 2.2$ to $7.27 \pm 3.93 \mathrm{pCi} / \mathrm{L}$ for gross alphaparticle radioactivity (reported as dissolved thorium-230), $1.1 \pm 0.8$ to $12.29 \pm 3.96 \mathrm{pCi} / \mathrm{L}$ for gross beta-particle radioactivity (reported as dissolved cesium-137), $-0.8 \pm 2.0$ to $2.9 \pm 2.1 \mathrm{pCi} / \mathrm{L}$ for cesium-137, and $-27 \pm 53$ to $81 \pm 44 \mathrm{pCi} / \mathrm{L}$ for potassium-40. None of these sample concentrations exceeded a U.S. Environmental Protection Agency maximum contaminant level (MCL) for drinking water.

Concentrations of trace elements in the water samples ranged from 10 to $137 \mu \mathrm{g} / \mathrm{L}$ for barium, 0.6 to $4.1 \mu \mathrm{g} / \mathrm{L}$ for chromium, $<10 \mu \mathrm{g} / \mathrm{L}$ for iron, 0.6 to $1.3 \mu \mathrm{g} / \mathrm{L}$ for lead, 6 to
$46 \mu \mathrm{g} / \mathrm{L}$ for lithium, 0.8 to $<2 \mu \mathrm{g} / \mathrm{L}$ for manganese, $<0.011 \mu \mathrm{g} / \mathrm{L}$ for mercury, 120 to $429 \mu \mathrm{g} / \mathrm{L}$ for strontium, and 16 to $238 \mu \mathrm{g} / \mathrm{L}$ for zinc. Concentrations of common ions in the water samples ranged from 25 to $78 \mathrm{mg} / \mathrm{L}$ for calcium, 12 to $32 \mathrm{mg} / \mathrm{L}$ for magnesium, 30 to $42 \mathrm{mg} / \mathrm{L}$ for silica, and 12 to $80 \mathrm{mg} / \mathrm{L}$ for sodium. Nutrient concentrations in water samples ranged from $<0.04 \mathrm{mg} / \mathrm{L}$ for ammonia (as nitrogen), $<0.008 \mathrm{mg} / \mathrm{L}$ for nitrite (as nitrogen), 0.5 to $7.8 \mathrm{mg} / \mathrm{L}$ for nitrite plus nitrate (as nitrogen), and 0.009 to $0.074 \mathrm{mg} / \mathrm{L}$ for orthophosphate (as phosphorus). None of these concentrations exceeded an established drinking water MCL, secondary MCL, or the U.S. Environmental Protection Agency action level for lead.

Concentrations of most purgeable organic compounds in water samples were less than the minimum reporting levels (MRL's). However, three concentrations of trichloromethane $(0.2276,1.527$, and $0.3126 \mu \mathrm{g} / \mathrm{L})$ and one concentration of bromodichloromethane $(0.2944 \mu \mathrm{g} / \mathrm{L})$ exceeded the MRL's. The MCL for total trihalomethanes, $100 \mu \mathrm{g} / \mathrm{L}$, was not exceeded in any water samples. Concentrations of insecticides were all less than their LRL's. Four herbicides, however, had concentrations or estimated concentrations that were greater than their LRL's. Concentrations of these herbicides ranged from 0.0031 to $0.0206 \mu \mathrm{g} / \mathrm{L}$ for atrazine, 0.0026 to $0.0195 \mu \mathrm{g} / \mathrm{L}$ for deethyl atrazine, and 0.0029 to $0.0155 \mu \mathrm{g} / \mathrm{L}$ for simazine. One estimated value of $0.0038 \mu \mathrm{g} / \mathrm{L}$ was reported for metolachlor. None of these concentrations exceeded an established MCL for drinking water.

Statistical analysis of the replicate sample pair indicated that, with 95 percent confidence, 132 of the 135 constituent concentrations of the replicate sample pair were statistically equivalent. The three constituent concentrations that were not equivalent were orthophosphorous (analyzed by the NWQL) and gross alpha-particle and gross beta-particle radioactivity (analyzed by the ISU-EML).

\section{SELECTED REFERENCES}

American Society for Testing and Materials, 1992, ASTM standards on precision and bias for various applications: Philadelphia, Pa., American Society for Testing and Materials Publication code number (PCN) 03-511092-34, 478 p.

Bartholomay, R.C., 1998, Effect of activities at the Idaho National Engineering and Environmental Laboratory on the water quality of the Snake River Plain aquifer in the Magic Valley study area, Idaho: U.S. Geological Survey Fact Sheet FS-052-98, 4 p.

Bartholomay, R.C., Edwards, D.D., and Campbell, L.J., 1992, Radionuclides, inorganic constituents, organic compounds, and bacteria in water from selected wells and springs from the southern boundary of the Idaho National Engineering Laboratory to the Hagerman area, Idaho, 1990: U.S. Geological Survey Open-File Report 92-91 (DOE/ID22102), $42 \mathrm{p}$. 
Bartholomay, R.C., Edwards, D.D., and Campbell, L.J.,1993, Radionuclides, inorganic constituents, organic compounds, and bacteria in water from selected wells and springs from the southern boundary of the Idaho National Engineering Laboratory to the Hagerman area, Idaho, 1991: U.S. Geological Survey Open-File Report 93-102 (DOE/ID22108), $42 \mathrm{p}$.

Bartholomay, R.C., Edwards, D.D., and Campbell, L.J.,1994a, Radionuclides, inorganic constituents, organic compounds, and bacteria in water from selected wells and springs from the southern boundary of the Idaho National Engineering Laboratory to the Hagerman area, Idaho, 1992: U.S. Geological Survey Open-File Report 94-76 (DOE/ID22114), $41 \mathrm{p}$.

Bartholomay, R.C., Edwards, D.D., and Campbell, L.J.,1994b, Radionuclides, stable isotopes, inorganic constituents, and organic compounds in water from selected wells and springs from the southern boundary of the Idaho National Engineering Laboratory to the Hagerman area, Idaho, 1993: U.S. Geological Survey Open-File Report 94-503 (DOE/ID22117), 35 p.

Bartholomay, R.C., Tucker, B.J., Ackerman, D.J., and Liszewski, M.J., 1997, Hydrologic conditions and distribution of radiochemical and chemical constituents in water, Snake River Plain aquifer, Idaho National Engineering Laboratory, Idaho, 1992 through 1995: U.S. Geological Survey Water-Resources Investigations Report 97-4086 (DOE/ID-22137), 57 p.

Bartholomay, R.C., Tucker, B.J., Davis, L.C., and Greene, M.R., 2000, Hydrologic conditions and distribution of selected constituents in water, Snake River Plain aquifer, Idaho National Engineering and Environmental Laboratory, Idaho, 1996 through 1998: U.S. Geological Survey WaterResources Investigations Report 00-4192 (DOE/ID-22167), $52 \mathrm{p}$.

Bartholomay, R.C., Twining, B.V., and Campbell, L.J., 1999, Radiochemical and chemical constituents in water from selected wells and springs from the southern boundary of the Idaho National Engineering and Environmental Laboratory to the Hagerman area, Idaho, 1998: U.S. Geological Survey Open-File Report 99-473 (DOE/ID-22161), 28 p.

Bartholomay, R.C., Twining, B.V., and Campbell, L.J., 2000, Radiochemical and chemical constituents in water from selected wells and springs from the southern boundary of the Idaho National Engineering and Environmental Laboratory to the Hagerman area, Idaho, 1999: U.S. Geological Survey Open-File Report 00-399 (DOE/ID-22169), 30 p.

Bartholomay, R.C., Twining, B.V., and Campbell, L.J., 2001, Radiochemical and chemical constituents in water from selected wells and springs from the southern boundary of the Idaho National Engineering and Environmental Laboratory to the Hagerman area, Idaho, 1999: U.S. Geological Survey Open-File Report 01-358 (DOE/ID-22176), 33 p.

Bartholomay, R.C., Williams, L.M., and Campbell, L.J., 1995, Radionuclides, stable isotopes, inorganic constituents, and organic compounds in water from selected wells and springs from the southern boundary of the Idaho National Engineering Laboratory to the Hagerman area, Idaho, 1994: U.S. Geological Survey Open-File Report 95-718 (DOE/ID22124), $37 \mathrm{p}$.

Bartholomay, R.C., Williams, L.M., and Campbell, L.J., 1996, Radionuclides, stable isotopes, inorganic constituents, and organic compounds in water from selected wells and springs from the southern boundary of the Idaho National Engineering Laboratory to the Hagerman area, Idaho, 1995: U.S. Geological Survey Open-File Report 96-496 (DOE/ID22130), 29 p.

Bartholomay, R.C., Williams, L.M., and Campbell, L.J., 1997a, Evaluation of radionuclide, inorganic constituent, and organic compound data from selected wells and springs from the southern boundary of the Idaho National Engineering Laboratory to the Hagerman area, Idaho, 1989 through 1992: U.S. Geological Survey Water-Resources Investigations Report 97-4007 (DOE/ID-22133), 73 p.

Bartholomay, R.C., Williams, L.M., and Campbell, L.J., 1997b, Radiochemical and chemical constituents in water from selected wells and springs from the southern boundary of the Idaho National Engineering Laboratory to the Hagerman area, Idaho, 1996: U.S. Geological Survey Open-File Report 97-360 (DOE/ID-22141), 29 p.

Bartholomay, R.C., Williams, L.M., and Campbell, L.J., 1998, Radiochemical and chemical constituents in water from selected wells and springs from the southern boundary of the Idaho National Engineering Laboratory to the Hagerman area, Idaho, 1997: U.S. Geological Survey Open-File Report 98-646 (DOE/ID-22152), 30 p.

Childress, C.J.O., Foreman, W.T., Connor, B.F., and Maloney, T.J., 1999, New reporting procedures based on long-term method detection levels and some considerations for interpretations of water-quality data provided by the U.S. Geological Survey National Water Quality Laboratory: U.S. Geological Survey Open-File Report 99-193, 19 p.

Claassen, H.C., 1982, Guidelines and techniques for obtaining water samples that accurately represent the water chemistry of an aquifer: U.S. Geological Survey Open-File Report 821024,49 p.

Currie, L.A., 1984, Lower limits of detection-definition and elaboration of a proposed position for radiological effluent and environmental measurements: U.S. Nuclear Regulatory Commission NUREG/CR-4007, 139 p.

Eisenbud, M., and Gesell, T.F., 1997, Environmental radioactivity from natural, industrial, and military sources, fourth edition: Academic Press, San Diego, California, 656 p.

Faires, L.M., 1992, Methods of analysis by the U.S. Geological Survey National Water Quality Laboratory-determination of metals in water by inductively coupled plasma-mass spectrometry: U.S. Geological Survey Open-File Report 92$634,28 \mathrm{p}$.

Faure, G., 1986, Principles of isotope geology, second edition: John Wiley \& Sons, Inc., New York, N.Y., 589 p.

Fishman, M.J., ed., 1993, Methods of analysis by the U.S. Geological Survey National Water Quality 
Laboratory-determination of inorganic and organic constituents in water and fluvial sediments: U.S. Geological Survey Open-File Report 93-125, 217 p.

Fishman, M.J., and Friedman, L.C., eds., 1989, Methods for determination of inorganic substances in water and fluvial sediments: U.S. Geological Survey Techniques of WaterResources Investigations, book 5, chap. A1, 545 p.

Friedman, L.C., and Erdmann, D.E., 1982, Quality assurance practices for the chemical and biological analyses of water and fluvial sediments: U.S. Geological Survey Techniques of Water-Resources Investigations, book 5, chap. A6, 181 p.

Garabedian, S.P., 1986, Application of a parameter-estimation technique to modeling the regional aquifer underlying the eastern Snake River Plain, Idaho: U.S. Geological Survey Water-Supply Paper 2278, 60 p.

Goerlitz, D.F., and Brown, Eugene, 1972, Methods for analysis of organic substances in water: U.S. Geological Survey Techniques of Water-Resources Investigations, book 5, chap. A3, $40 \mathrm{p}$.

Hall, F., 2002, Sampling and analysis plan for water surveillance monitoring activities: State of Idaho INEEL Oversight Program, 40 p.

Hardy, M.A., Leahy, P.P., and Alley, W.M., 1989, Well installation and documentation, and ground-water sampling protocols for the pilot National Water-Quality Assessment Program: U.S. Geological Survey Open-File Report 89-396, $36 \mathrm{p}$.

Idaho Department of Health and Welfare, 1989, Idaho regulations for public drinking water systems: Boise, Rules and Regulations of the Department of Health and Welfare, title 1, chapter 8 [not paged].

INEEL Oversight Program, 2003, Environmental Surveillance Program Annual Report, 2002: State of Idaho INEEL Oversight Program, in press.

Jones, B.E., 1987, Quality control manual of the U.S. Geological Survey's National Water Quality Laboratory: U.S. Geological Survey Open-File Report 87-457, 17 p.

Kjelstrom, L.C., 1992, Assessment of spring discharge to the Snake River, Milner Dam to King Hill, Idaho: U.S. Geological Survey Open-File Report 92-147 (Water Fact Sheet), [2] p.

Knobel, L.L., Orr, B.R., and Cecil, L.D., 1992, Summary of background concentrations of selected radiochemical and chemical constituents in ground water from the Snake River Plain aquifer, Idaho — estimated from an analysis of previously published data: Journal of the Idaho Academy of Science, v. 28, no. 1, p. 48-61.

Mann, L.J., 1986, Hydraulic properties of rock units and chemical quality of water for INEL-1 - a 10,365-foot deep test hole drilled at the Idaho National Engineering Laboratory, Idaho: U.S. Geological Survey Water-Resources Investigations Report 86-4020 (DOE/ID-22070), 23 p.

Mann, L.J., 1989, Tritium concentrations in flow from selected springs that discharge to the Snake River, Twin FallsHagerman area, Idaho: U.S. Geological Survey Water-
Resources Investigations Report 89-456 (DOE/ID-22084), $20 \mathrm{p}$.

Mann, L.J., 1996, Quality-assurance plan and field methods for quality-of-water activities, U.S. Geological Survey, Idaho National Engineering Laboratory, Idaho: U.S. Geological Survey Open-File Report 96-615 (DOE/ID-22132), 37 p.

Mann, L.J., and Cecil, L.D., 1990, Tritium in ground water at the Idaho National Engineering Laboratory, Idaho: U.S. Geological Survey Water-Resources Investigations Report 90- 4090 (DOE/ID-22090), 35 p.

Mann, L.J., and Knobel, L.L., 1990, Radionuclides, metals, and organic compounds in water, eastern part of A\&B Irrigation District, Minidoka County, Idaho: U.S. Geological Survey Open-File Report 90-191 (DOE/ID-22087), 36 p.

Mann, L.J., and Low, W.H., 1994, Tritium, stable isotopes, and nitrogen in flow from selected springs that discharge to the Snake River, Twin Falls-Hagerman area, Idaho, 1990-93: U.S. Geological Survey Water-Resources Investigations Report 94-4247 (DOE/ID-22119), 21 .

Pittman, J.R., Jensen, R.G., and Fischer, P.R., 1988, Hydrologic conditions at the Idaho National Engineering Laboratory, 1982-1985: U.S. Geological Survey Water-Resources Investigations Report 89-4008 (DOE/ID-22078), 73 p.

Pritt, J.W., and Raese, J.W., eds., 1995, Quality assurance/ quality control manual-National Water Quality Laboratory: U.S. Geological Survey Open-File Report 95-443, 35 p.

Stevens, H.H., Jr., Ficke, J.F., and Smoot, G.F., 1975, Water temperature-influential factors, field measurement, and data presentation: U.S. Geological Survey Techniques of Water-Resources Investigations, book 5, chap. D1, 65 p.

Thatcher, L.L., Janzer, V.J., and Edwards, K.W., 1977, Methods for determination of radioactive substances in water and fluvial sediments: U.S. Geological Survey Techniques of Water-Resources Investigations, book 5, chap. A5, 95 p.

Timme, P.J., 1995, National Water Quality Laboratory, 1995 services catalog: U.S. Geological Survey Open-File Report 95-352, $120 \mathrm{p}$.

Twining, B.V., 2002, Tritium in flow from selected springs that discharge to the Snake River, Twin Falls-Hagerman area, Idaho, 1994-99: U.S. Geological Survey Open-File Report 02-185 (DOE/ID-22180), 12 p.

Twining, B.V., Rattray, G., and Campbell, L.J., 2003, Radiochemical and chemical constituents in water from selected wells and springs from the southern boundary of the Idaho National Engineering and Environmental Laboratory to the Hagerman area, Idaho, 2001: U.S. Geological Survey Open-File Report 03-168 (DOE/ID-22185), 32 p.

U.S. Environmental Protection Agency, 1994, EPA drinking water regulations and health advisories: U.S. Environmental Protection Agency, Office of Water, EPA 822 R-94-001, $11 \mathrm{p}$.

U.S. Environmental Protection Agency, 2000, Protection of environment, Code of Federal Regulations 40: Office of the Federal Register, National Archives and Records Administration, pts. 136 to 149,901 p. 


\section{Radiochemical and Chemical Constituents in Water from Selected Wells and Springs}

U.S. Environmental Protection Agency, 2003, EPA National Primary and Secondary Drinking Water Standards: EPA 816-F-03-016, 6 p.

Volk, W., 1969, Applied statistics for engineers (2d ed.): New York, McGraw-Hill Book Company, 415 p.

Wegner, S.J., and Campbell, L.J., 1991, Radionuclides, chemical constituents, and organic compounds in water from designated wells and springs from the southern boundary of the Idaho National Engineering Laboratory to the Hagerman area, Idaho, 1989: U.S. Geological Survey Open-File Report 91-232 (DOE/ID-22098), 49 p.

Wershaw, R.L., Fishman, M.J., Grabbe, R.R., and Lowe, L.E., 1987, Methods for the determination of organic substances in water and fluvial sediments: U.S. Geological Survey Techniques of Water-Resources Investigations, book 5, chap. A3, $80 \mathrm{p}$.

Whitehead, R.L., 1986, Geohydrologic framework of the Snake River Plain, Idaho and eastern Oregon: U.S. Geological Survey Hydrologic Investigations Atlas HA-681, 3 sheets, scale 1:1,000,000.

Wilde, F.D., Radtke, D.B., Gibs, J., and Iwatsubo, R.T., 1998, National field manual for the collection of water-quality data: U.S. Geological Survey Techniques of Water-Resources Investigations, book 9, sections A1, A2, A3, A6 [variously paged].

Wilde, F.D., Radtke, D.B., Gibs, J., and Iwatsubo, R.T., 1999, National field manual for the collection of water-quality data: U.S. Geological Survey Techniques of Water-Resources Investigations, book 9, section A4 [variously paged].
Wilde, F.D., Radtke, D.B., Gibs, J., and Iwatsubo, R.T., 2002, National field manual for the collection of water-quality data: U.S. Geological Survey Techniques of Water-Resources Investigations, book 9, section A5 [variously paged].

Williams, L.M., 1996, Evaluation of quality-assurance/qualitycontrol data collected by the U.S. Geological Survey for water-quality activities at the Idaho National Engineering and Environmental Laboratory, Idaho, 1989 through 1993: U.S. Geological Survey Water-Resources Investigations Report 96-4148 (DOE/ID-22129), 116 p.

Williams, L.M., Bartholomay, R.C., and Campbell, L.J., 1998, Evaluation of quality-assurance/quality-control data collected by the U.S. Geological Survey from wells and springs between the southern boundary of the Idaho National Engineering and Environmental Laboratory and the Hagerman area, Idaho, 1989 through 1995: U.S. Geological Survey Water-Resources Investigations Report 98-4206 (DOE/ID-22150), 83 p.

Wood, W.W., 1981, Guidelines for collection and field analysis of ground-water samples for selected unstable constituents: U.S. Geological Survey Techniques of Water-Resources Investigations, book 1, chap. D2, $24 \mathrm{p}$.

Zaugg, S.D., Sandstrom, M.W., Smith, S.G., and Fehlberg, K.M., 1995, Methods of analysis by the U.S. Geological Survey National Water Quality Laboratory-determination of pesticides in water by $\mathrm{C}-18$ solid-phase extraction and capillary-column gas chromatography/mass spectrometry with selected-ion monitoring: U.S. Geological Survey OpenFile Report 95-181, 49 p. 
Table 1. Containers and preservatives used for water-sample collection.

[Abbreviations: $\mathrm{L}$, liter; $\mathrm{mL}$, milliliter; $\mu \mathrm{m}$, micrometer; ${ }^{\circ} \mathrm{C}$, degrees Celsius. Chemical formulas: $\mathrm{HNO}_{3}$, nitric acid; $\mathrm{HCl}$, hydrochloric acid. Chilled samples were shipped by overnight- delivery mail. Analyzing laboratory: NWQL, U.S. Geological Survey National Water Quality Laboratory; ISU-EML, Idaho State University Environmental Monitoring Laboratory]

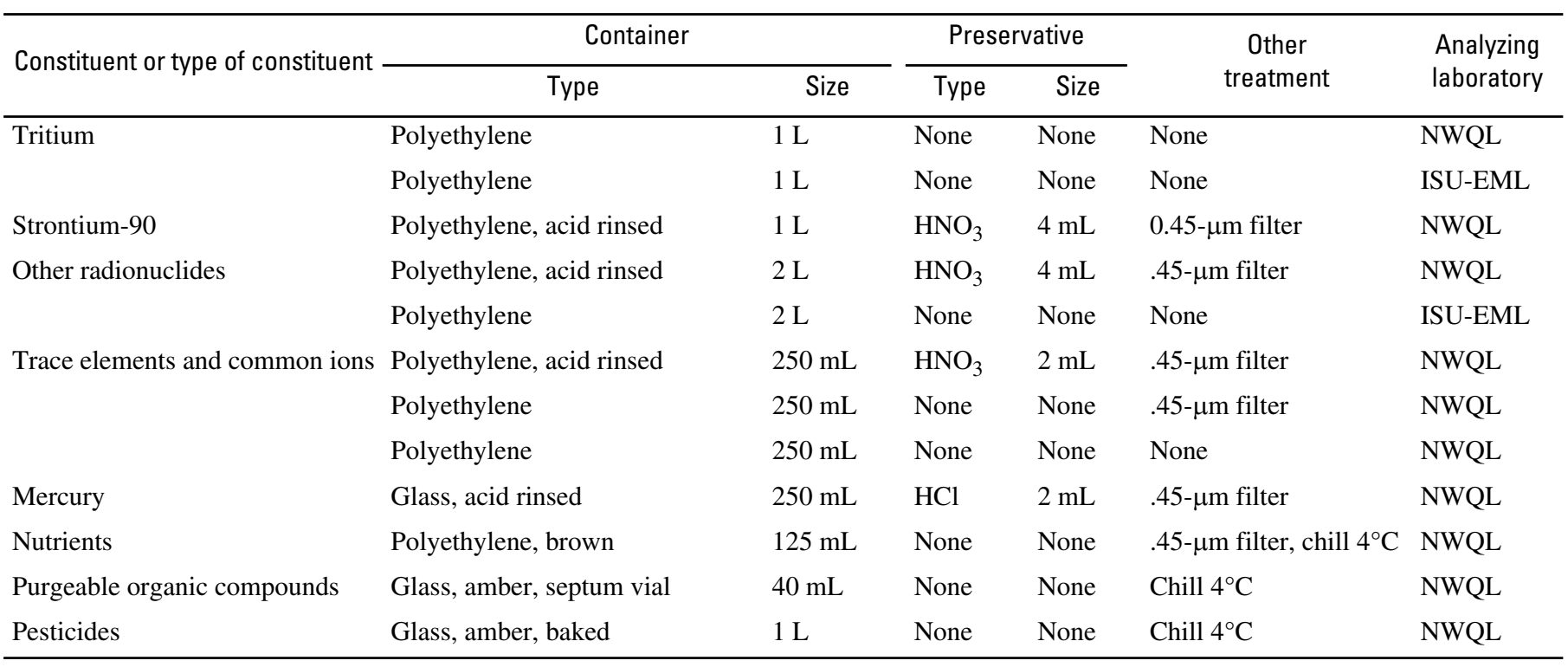

Table 2. Results of field measurements of water for $\mathrm{pH}$, specific conductance, and temperature from selected wells and springs, eastern Snake River Plain.

[See figure 2 for location of sites. Site type: I, irrigation; QA, quality assurance (MV-8 is a replicate of MV-1); Sp, spring; D, dairy; H, domestic; C, commercial; $\mathrm{S}$, stock; O, observation. Date sampled: month/day/year. Units: $\mathrm{pH}$, negative base-10 logarithm of hydrogen-ion activity in moles per liter; specific conductance, microsiemens per centimeter at $25^{\circ} \mathrm{C}$ (degrees Celsius); temperature in degrees Celsius, ${ }^{\circ} \mathrm{C}$; The National Secondary Drinking Water Standard for pH is 6.5-8.5 (U.S. Environmental Protection Agency, 2003)

\begin{tabular}{|c|c|c|c|c|c|c|}
\hline Site identifier & Site ID & Site type & Date sampled & $\mathrm{pH}$ & $\begin{array}{c}\text { Specific } \\
\text { conductance }\end{array}$ & Temperature \\
\hline MV-1 & 424313113343501 & I & $6 / 24 / 02$ & 7.9 & 586 & 13.6 \\
\hline MV-8 & 433000113000001 & QA & $6 / 24 / 02$ & 7.9 & 586 & 13.6 \\
\hline MV-11 & 4240211135900 & I & $6 / 25 / 02$ & 7.4 & 858 & 13.6 \\
\hline MV-15 & 13091500 & $\mathrm{Sp}$ & $8 / 6 / 02$ & 7.8 & 601 & 15.8 \\
\hline MV-18 & 13093400 & $\mathrm{Sp}$ & $8 / 6 / 02$ & 8.0 & 664 & 14.6 \\
\hline MV-21 & 424807114505701 & $\mathrm{D}$ & $8 / 6 / 02$ & 7.7 & 343 & 16.5 \\
\hline MV-23 & 424037113423201 & I & $6 / 24 / 02$ & 7.7 & 691 & 14.5 \\
\hline MV-24A & 424224113484302 & $\mathrm{H}$ & $8 / 5 / 02$ & 7.6 & 1,009 & 15.2 \\
\hline MV-25 & 423945114110301 & $\mathrm{H}$ & $8 / 6 / 02$ & 7.6 & 706 & 13.9 \\
\hline MV-26 & 424359114240901 & I & $8 / 5 / 02$ & 7.9 & 453 & 13.6 \\
\hline MV-29 & 42482411463801 & I & $8 / 7 / 02$ & 8.0 & 342 & 14.1 \\
\hline MV-30 & 423935114263701 & $\mathrm{C}$ & $8 / 5 / 02$ & 7.7 & 658 & 14.8 \\
\hline MV-35 & 425307114122301 & I & $8 / 6 / 02$ & 8.1 & 286 & 14.3 \\
\hline MV-37 & 425726114344901 & $\mathrm{H}$ & $8 / 7 / 02$ & 7.4 & 472 & 15.0 \\
\hline MV-40 & 425104114180001 & I & $6 / 25 / 02$ & 8.0 & 324 & 14.5 \\
\hline MV-41 & 425619114454101 & I & $8 / 6 / 02$ & 7.4 & 716 & 14.0 \\
\hline MV-59 & 430805113102401 & S & $6 / 24 / 02$ & 8.3 & 308 & 16.3 \\
\hline MV-61 & 432019112563201 & $\mathrm{O}$ & $8 / 8 / 02$ & 8.0 & 388 & 14.8 \\
\hline
\end{tabular}


Table 3. Maximum contaminant levels for selected radionuclides and types of radioactivity in drinking water.

[The maximum contaminant levels (MCL's) were established pursuant to the recommendations of the U.S. Environmental Protection Agency (2003) for community water systems and are included for comparison with results from this study. MCL's given for strontium-90 and tritium are concentrations assumed to produce a total body or organ dose of 4 millirem per year (mrem/yr) of beta-particle radiation. The MCL given for gross alpha-particle radioactivity excludes radon and uranium. Abbreviation: $\mathrm{pCi} / \mathrm{L}$, picocurie per liter]

\begin{tabular}{lc}
\hline \multicolumn{1}{c}{ Radionuclide or type of radioactivity } & Maximum contaminant level \\
\hline Tritium & $20,000 \mathrm{pCi} / \mathrm{L}$ \\
Strontium-90 & $8 \mathrm{pCi} / \mathrm{L}$ \\
Gross alpha-particle radioactivity & $15 \mathrm{pCi} / \mathrm{L}$ \\
Gross beta-particle and gamma radioactivity & $4 \mathrm{mrem} / \mathrm{yr}$ \\
\hline
\end{tabular}

Table 4. Concentrations of tritium and strontium-90 in water from selected wells and springs, eastern Snake River Plain1

[See figure 2 for location of sites. Analyses were performed by the U.S. Geological Survey National Water Quality Laboratory (NWQL) and Idaho State University Environmental Monitoring Laboratory (ISU-EML) using the following methods: tritium by standard liquid scintillation counting (ISU-EML) and electrolytic enrichment liquid scintillation counting (both laboratories); strontium-90 by gas proportional counting. Analytical results and uncertainties-for example $-0.0337 \pm 0.17$-in picocuries per liter. Analytical uncertainties are reported as $2 \mathbf{s}$. Concentrations that exceed the reporting level of $3 \mathbf{s}$ are shown in boldface type. Symbol: *, quality-assurance sample (MV-8 is a replicate of MV-1). ISU-EML results for MV-1, $-8,-11,-18,-23$ (nonenrichment method only), -29 (enrichment method only), -40 , and -59 are averages of lab split samples or lab recounts]

\begin{tabular}{|c|c|c|c|c|}
\hline Site identifier & $\begin{array}{l}\text { Tritium, NWQL } \\
\text { (Enrichment) }\end{array}$ & $\begin{array}{l}\text { Tritium, ISU-EML } \\
\text { (Enrichment) }\end{array}$ & Tritium, ISU-EML & Strontium-90, NWOL \\
\hline MV-1 & $26.9 \pm 1.9$ & $28 \pm 7$ & $0 \pm 90$ & $-.0337 \pm 0.17$ \\
\hline MV-8* & $27.8 \pm 1.9$ & $30 \pm 7$ & $10 \pm 90$ & $.114 \pm 0.19$ \\
\hline MV-11 & $43 \pm 2.6$ & $44 \pm 7$ & $0 \pm 90$ & $.0686 \pm 0.18$ \\
\hline MV-15 & $35.5 \pm 2.6$ & $35 \pm 7$ & $50 \pm 90$ & $.159 \pm 0.16$ \\
\hline MV-18 & $33.9 \pm 2.6$ & $29 \pm 5$ & $-20 \pm 64$ & $.0156 \pm 0.16$ \\
\hline$M V-21$ & $8.0 \pm 1.0$ & $17 \pm 6$ & $-10 \pm 90$ & $.0827 \pm 0.16$ \\
\hline $\mathrm{MV}-23$ & $31.0 \pm 1.9$ & $40 \pm 5$ & $30 \pm 90$ & $.0683 \pm 0.20$ \\
\hline MV-24A & $47.7 \pm 3.2$ & $34 \pm 8$ & $-30 \pm 90$ & $.105 \pm 0.22$ \\
\hline MV-25 & $37.1 \pm 2.6$ & $32 \pm 8$ & $40 \pm 90$ & $-.00291 \pm 0.15$ \\
\hline MV-26 & $5.8 \pm 1.0$ & $10 \pm 6$ & $-40 \pm 90$ & $.223 \pm 0.34$ \\
\hline MV-29 & $1.3 \pm 1.0$ & $3 \pm 3$ & $-30 \pm 64$ & $-.0255 \pm 0.16$ \\
\hline MV-30 & $37.1 \pm 2.6$ & $36 \pm 6$ & $30 \pm 90$ & $.0409 \pm 0.19$ \\
\hline MV-35 & $2.9 \pm 1.0$ & $8 \pm 6$ & $-40 \pm 90$ & $.0696 \pm 0.16$ \\
\hline MV-37 & $36.5 \pm 2.6$ & $33 \pm 7$ & $50 \pm 90$ & $.122 \pm 0.18$ \\
\hline MV-40 & $5.8 \pm 1.0$ & $16 \pm 7$ & $40 \pm 90$ & $.131 \pm 0.20$ \\
\hline MV-41 & $35.5 \pm 2.6$ & $37 \pm 6$ & $60 \pm 90$ & $.108 \pm 0.16$ \\
\hline MV-59 & $-.3 \pm 1.0$ & $2 \pm 6$ & $-60 \pm 90$ & $.0726 \pm 0.20$ \\
\hline MV-61 & $16.3 \pm 1.3$ & $24 \pm 6$ & $0 \pm 90$ & $-.0115 \pm 0.15$ \\
\hline
\end{tabular}


Table 5. Concentrations of gross alpha-particle and gross beta-particle radioactivity in water from selected wells and springs, eastern Snake River Plain.

[See figure 2 for location of sites. Analyses were performed by the U.S. Geological Survey National Water Quality Laboratory (NWQL) and the Idaho State University Environmental Monitoring Laboratory (ISU-EML) using a residue procedure. Analytical results and uncertainties-for example 5.77 $\pm 3.69-i n$ picocuries per liter. Analytical uncertainties are reported as $2 \mathbf{s}$. Concentrations that equal or exceed the reporting level of $3 \mathbf{s}$ are shown in boldface type. Symbols: *, quality-assurance sample (MV-8 is a replicate of MV-1); E, estimated result (a result may be estimated for a variety of laboratory-specific reasons; for instance, the result may lie outside the calibrated range of the instrument; estimated results have increased uncertainty (Childress and others, 1999, pp. 8-10)). ISU-EML gross alpha-particle and gross beta-particle results for MV-11, MV-18 and MV-29 are averages of lab split samples]

\begin{tabular}{|c|c|c|c|c|}
\hline $\begin{array}{c}\text { Site } \\
\text { identifier }\end{array}$ & $\begin{array}{c}\text { Gross alpha-particle, } \\
\text { as dissolved thorium-230, } \\
\text { NWQL }\end{array}$ & $\begin{array}{c}\text { Gross alpha-particle, } \\
\text { as total thorium-230, } \\
\text { ISU-EML }\end{array}$ & $\begin{array}{c}\text { Gross beta-particle, } \\
\text { as dissolved cesium-137, } \\
\text { NWQL }\end{array}$ & $\begin{array}{c}\text { Gross beta-particle, } \\
\text { as total cesium-137, } \\
\text { ISU-EML }\end{array}$ \\
\hline MV-1 & $5.77 \pm 3.69$ & $-.9 \pm 1.6$ & $9.67 \pm 2.50$ & $2.8 \pm 0.9$ \\
\hline $\mathrm{MV}-8^{*}$ & $4.89 \pm 3.79$ & $4.2 \pm 1.8$ & $10.11 \pm 2.55$ & $5.5 \pm 1.0$ \\
\hline MV-11 & $5.91 \pm 5.81$ & $1.8 \pm 1.6$ & $10.50 \pm 3.07$ & $5.15 \pm 0.8$ \\
\hline MV-15 & $4.22 \pm 3.91$ & $0.6 \pm 1.6$ & $10.68 \pm 2.47 \mathrm{E}$ & $3.6 \pm 1.0$ \\
\hline MV-18 & $1.99 \pm 4.72$ & $2.15 \pm 1.3$ & $8.90 \pm 2.95$ & $2.8 \pm 0.7$ \\
\hline MV-21 & $1.95 \pm 2.11$ & $1.0 \pm 1.4$ & $4.37 \pm 1.35$ & $2.7 \pm 0.8$ \\
\hline MV-23 & $2.56 \pm 3.65$ & $-.9 \pm 2.2$ & $8.62 \pm 2.86$ & $4.0 \pm 1.1$ \\
\hline MV-24A & $5.10 \pm 4.63$ & $2.1 \pm 2.4$ & $12.29 \pm 3.96$ & $5.1 \pm 1.2$ \\
\hline MV-25 & $3.52 \pm 3.19$ & $4.2 \pm 2.2$ & $10.67 \pm 2.92$ & $4.0 \pm 1.1$ \\
\hline MV-26 & $2.15 \pm 2.10$ & $0.4 \pm 1.4$ & $4.54 \pm 1.85$ & $3.1 \pm 0.9$ \\
\hline MV-29 & $3.16 \pm 2.33$ & $-.2 \pm 0.9$ & $3.81 \pm 1.32$ & $2.1 \pm 0.6$ \\
\hline MV-30 & $7.27 \pm 3.93$ & $1.0 \pm 2.0$ & $7.80 \pm 2.66$ & $4.7 \pm 1.0$ \\
\hline MV-35 & $1.75 \pm 1.88$ & $1.5 \pm 1.2$ & $3.65 \pm 1.17$ & $1.1 \pm 0.8$ \\
\hline MV-37 & $3.23 \pm 2.99$ & $.6 \pm 1.6$ & $5.44 \pm 1.82 \mathrm{E}$ & $3.5 \pm 0.9$ \\
\hline MV-40 & $1.42 \pm 2.07$ & $.7 \pm 1.5$ & $4.06 \pm 1.18$ & $1.6 \pm 0.8$ \\
\hline MV-41 & $3.22 \pm 6.56$ & $5.2 \pm 2.2$ & $8.35 \pm 3.20$ & $4.3 \pm 1.1$ \\
\hline MV-59 & $.95 \pm 1.88$ & $3.3 \pm 1.2$ & $4.71 \pm 1.18$ & $2.3 \pm 0.8$ \\
\hline MV-61 & $1.97 \pm 2.32$ & $3.4 \pm 1.4$ & $4.77 \pm 1.49$ & $1.4 \pm 0.9$ \\
\hline
\end{tabular}


Table 6. Concentrations of cesium-137 and potassium- 40 in water from selected wells and springs, eastern Snake River Plain.

[See figure 2 for location of sites. Analyses were performed by the Idaho State University Environmental Monitoring Laboratory using gamma spectrometry. Analytical results and uncertainties—for example - $0.8 \pm 1.8$-in picocuries per liter. Analytical uncertainties are reported as $2 \mathbf{s}$. Concentrations that equal or exceed the reporting level of $3 \mathbf{s}$ are shown in boldface type. Symbol: *, quality-assurance sample (MV-8 is a replicate of MV-1). Results for MV-11, MV-18, and MV-29 are averages of lab split samples]

\begin{tabular}{|c|c|c|}
\hline Site identifier & Cesium-137 & Potassium-40 \\
\hline$\overline{M V-1}$ & $-.8 \pm 1.8$ & $81 \pm 44$ \\
\hline MV-8* & $-.2 \pm 1.4$ & $35 \pm 43$ \\
\hline MV-11 & $.3 \pm 1.1$ & $-16 \pm 38$ \\
\hline MV-15 & $.5 \pm 1.6$ & $27 \pm 42$ \\
\hline MV-18 & $.3 \pm 1.0$ & $54 \pm 30$ \\
\hline MV-21 & $.3 \pm 1.5$ & $-9 \pm 40$ \\
\hline MV-23 & $-.2 \pm 1.3$ & $20 \pm 43$ \\
\hline MV-24A & $1.4 \pm 2.3$ & $-5 \pm 54$ \\
\hline MV-25 & $2.9 \pm 2.1$ & $77 \pm 44$ \\
\hline MV-26 & $.4 \pm 2.3$ & $2 \pm 53$ \\
\hline MV-29 & $-.4 \pm 1.1$ & $64 \pm 30$ \\
\hline MV-30 & $-.2 \pm 1.6$ & $6 \pm 42$ \\
\hline MV-35 & $.4 \pm 1.4$ & $-11 \pm 41$ \\
\hline MV-37 & $.6 \pm 1.7$ & $-27 \pm 53$ \\
\hline MV-40 & $-.8 \pm 2.0$ & $11 \pm 58$ \\
\hline MV-41 & $.4 \pm 1.7$ & $-18 \pm 40$ \\
\hline MV-59 & $.6 \pm 1.7$ & $20 \pm 43$ \\
\hline MV-61 & $-.7 \pm 2.0$ & $-5 \pm 41$ \\
\hline
\end{tabular}

Table 7. Maximum or secondary maximum contaminant levels and laboratory reporting levels of selected trace elements in drinking water.

[The maximum contaminant levels (MCL's) were established pursuant to the recommendations of the U.S. Environmental Protection Agency (2003) for community water systems and are included for comparison with results from this study Secondary maximum contaminant levels—in brackets-are from U.S. Environmental Protection Agency (2003). Units are in micrograms per liter ( $\mu \mathrm{g} / \mathrm{L})$. Symbols: *, lead has an action level of $15 \mu \mathrm{g} / \mathrm{L} ;{ }^{* *}$, MCL has not been established]

\begin{tabular}{lcc}
\hline \multicolumn{1}{c}{ Trace element } & $\begin{array}{c}\text { Maximum or secondary maximum } \\
\text { contaminant level }\end{array}$ & Laboratory reporting level \\
\hline Barium & 2,000 & .9 \\
Chromium & 100 & .8 \\
Iron & {$[300]$} & 10 \\
Lead & $*$ & 1 \\
Lithium & $* *$ & 3.9 \\
Manganese & {$[50]$} & 2 \\
Mercury & 2 & .011 \\
Strontium & $* *$ & .6 \\
Zinc & {$[5,000]$} & 24 \\
\hline
\end{tabular}


Table 8. Concentrations of dissolved trace elements in water from selected wells and springs, eastern Snake River Plain1

[See figure 2 for location of sites. Analyses were performed by the U.S. Geological Survey National Water Quality Laboratory. Analytical results in micrograms per liter. Symbols: <, concentration is less than the laboratory reporting level (used to indicate that the detection of the constituent is unclear); *, quality- assurance sample (MV-8 is a replicate of MV-1); E, estimated result (a result may be estimated for a variety of laboratory-specific reasons; for instance, the result may lie outside of the calibrated range of the instrument; estimated results have increased uncertainty (Childress and others, 1999, pp. 8-10))]

\begin{tabular}{lccccccccc}
\hline \multicolumn{1}{c}{ Site identifier } & Barium & Chromium & Iron & Lead & Lithium & Manganese & Mercury & Strontium & Zinc \\
\hline MV-1 & 63 & $.8 \mathrm{E}$ & $<10$ & $<1$ & 38 & $<2$ & $<.011$ & 294 & $<24$ \\
MV-8* & 63 & $.8 \mathrm{E}$ & $<10$ & $<1$ & 39 & $<2$ & $<.011$ & 294 & $<24$ \\
MV-11 & 102 & 1.4 & $<10$ & $<1$ & 46 & $<2$ & $<.011$ & 429 & $<24$ \\
MV-15 & 72 & 1.0 & $<10$ & $<1$ & 29 & $<2$ & $<.011$ & 276 & $<24$ \\
MV-18 & 54 & 1.3 & $<10$ & $<1$ & 39 & $<2$ & $<.011$ & 306 & $<24$ \\
MV-21 & 18 & 3.2 & $<10$ & $<1$ & 14 & $<2$ & $<.011$ & 156 & $<24$ \\
MV-23 & 93 & 3.0 & $5.7 \mathrm{E}$ & $.7 \mathrm{E}$ & 36 & $<2$ & $<.011$ & 336 & 166 \\
MV-24A & 137 & 1.1 & $<10$ & 1.3 & 45 & $<2$ & $<.011$ & 394 & 32 \\
MV-25 & 57 & $.6 \mathrm{E}$ & $<10$ & 1.3 & 27 & $<2$ & $<.011$ & 273 & 82 \\
MV-26 & 25 & 2.1 & $<10$ & 1.3 & 29 & $<2$ & $<.011$ & 211 & $<24$ \\
MV-29 & 18 & 3.0 & $8.7 \mathrm{E}$ & $<1$ & 20 & $<2$ & $<.011$ & 156 & $<24$ \\
MV-30 & 65 & 1.2 & $<10$ & $.6 \mathrm{E}$ & 31 & $<2$ & $<.011$ & 303 & $16 \mathrm{E}$ \\
MV-35 & 11 & 3.5 & $<10$ & $<1$ & 10 & $<2$ & $<.011$ & 132 & $<24$ \\
MV-37 & 49 & $.6 \mathrm{E}$ & $<10$ & $<1$ & 6 & $<2$ & $<.011$ & 205 & 82 \\
MV-40 & 15 & 3.5 & $<10$ & $<1$ & 10 & $<2$ & $<.011$ & 144 & $<24$ \\
MV-41 & 67 & .8 & $<10$ & $<1$ & 8 & $<2$ & $<.011$ & 306 & $<24$ \\
MV-59 & 10 & 4.0 & $<10$ & $.8 \mathrm{E}$ & 13 & $<2$ & $<.011$ & 120 & 238 \\
MV-61 & 20 & 4.1 & $<10$ & $.9 \mathrm{E}$ & 24 & $.8 \mathrm{E}$ & $<.011$ & 165 & 54 \\
\hline
\end{tabular}

Table 9. Maximum contaminant levels and laboratory reporting levels of selected common ions and nutrients in drinking water.

[The maximum contaminant levels (MCL's) were established pursuant to the recommendations of the U.S. Environmental Protection Agency (2003) for community water systems and are included for comparison with results from this study. Laboratory reporting levels (LRL's) are from the U.S. Geological Survey National Water Quality Laboratory web site (http://nwql.cr.usgs.gov/usgs/ltmdl). Units are in milligrams per liter (mg/L). Symbol: **, MCL has not been established]

\begin{tabular}{lcc}
\hline \multicolumn{1}{c}{ Constituent } & Maximum contaminant level & Laboratory reporting level \\
\hline Calcium & $* *$ & .012 \\
Magnesium & $* *$ & .008 \\
Silica & $* *$ & .13 \\
Sodium 1 & $* *$ & .09 \\
Ammonia (as nitrogen) & $* *$ & .041 \\
Nitrite (as nitrogen) & 1 & .008 \\
Nitrate (as nitrogen) & 10 & $.047^{2}$ \\
Orthophosphate (as phosphorus) & $* *$ & .018 \\
\hline
\end{tabular}

${ }^{1}$ Idaho Department of Health and Welfare (1989) recommends an optimum concentration of $20 \mathrm{mg} / \mathrm{L}$ for pub-

lic drinking-water supplies.

${ }^{2}$ Nitrite plus nitrate (as nitrogen) 


\section{Radiochemical and Chemical Constituents in Water from Selected Wells and Springs}

Table 10. Concentrations of dissolved common ions and nutrients in water from selected wells and springs, eastern Snake River Plain.

[See figure 2 for location of sites. Analyses were performed by the U.S. Geological Survey National Water Quality Laboratory. Analytical results in milligrams per liter. Symbols: <, concentration is less than the laboratory reporting level (used to indicate that the detection of the constituent is unclear); ${ }^{*}$, quality-assurance sample (MV-8 is a replicate of MV-1); E, estimated result (a result may be estimated for a variety of laboratory-specific reasons; for instance, the result may lie outside the calibrated range of the instrument; estimated results have increased uncertainty (Childress and others, 1999, pp 8-10))]

\begin{tabular}{|c|c|c|c|c|c|c|c|c|}
\hline $\begin{array}{c}\text { Site } \\
\text { identifier }\end{array}$ & Calcium & Magnesium & Silica & Sodium & $\begin{array}{c}\text { Ammonia } \\
\text { (as nitrogen) }\end{array}$ & $\begin{array}{c}\text { Nitrite (as } \\
\text { nitrogen) }\end{array}$ & $\begin{array}{l}\text { Nitrite plus nitrate } \\
\text { (as nitrogen) }\end{array}$ & $\begin{array}{l}\text { Orthophosphate } \\
\text { (as phosphorus) }\end{array}$ \\
\hline MV-1 & 50 & 19 & 39 & 37 & $<.04$ & $<.008$ & 1.1 & .019 \\
\hline MV-8* & 50 & 19 & 39 & 37 & $<.04$ & $<.008$ & 1.2 & $.015 \mathrm{E}$ \\
\hline MV-11 & 78 & 29 & 37 & 52 & $<.04$ & $<.008$ & 5.5 & $.016 \mathrm{E}$ \\
\hline MV-15 & 56 & 19 & 40 & 34 & $<.04$ & $<.008$ & 1.9 & $.012 \mathrm{E}$ \\
\hline MV-18 & 59 & 23 & 38 & 35 & $<.04$ & $<.008$ & 2.4 & .023 \\
\hline MV-21 & 31 & 15 & 34 & 15 & $<.04$ & $<.008$ & 1.0 & $.016 \mathrm{E}$ \\
\hline MV-23 & 76 & 22 & 30 & 32 & $<.04$ & $<.008$ & 5.7 & .044 \\
\hline MV-24A & 76 & 32 & 35 & 80 & $<.04$ & $<.008$ & 7.8 & .021 \\
\hline MV-25 & 60 & 26 & 37 & 45 & $<.04$ & $<.008$ & 3.9 & .074 \\
\hline MV-26 & 42 & 16 & 33 & 21 & $<.04$ & $<.008$ & 1.0 & $.009 \mathrm{E}$ \\
\hline MV-29 & 31 & 14 & 33 & 15 & $<.04$ & $<.008$ & .5 & $.013 \mathrm{E}$ \\
\hline MV-30 & 63 & 21 & 37 & 37 & $<.04$ & $<.008$ & 2.4 & $.015 \mathrm{E}$ \\
\hline MV-35 & 25 & 12 & 32 & 12 & $<.04$ & $<.008$ & .5 & $.013 \mathrm{E}$ \\
\hline MV-37 & 54 & 17 & 31 & 17 & $<.04$ & $<.008$ & 1.9 & $.012 \mathrm{E}$ \\
\hline MV-40 & 30 & 14 & 33 & 14 & $<.04$ & $<.008$ & .6 & .02 \\
\hline MV-41 & 64 & 27 & 42 & 42 & $<.04$ & $<.008$ & 2.7 & .062 \\
\hline MV-59 & 25 & 13 & 35 & 16 & $<.04$ & $<.008$ & .7 & $.010 \mathrm{E}$ \\
\hline MV-61 & 37 & 15 & 32 & 16 & $<.04$ & $<.008$ & 1.1 & $<.02$ \\
\hline
\end{tabular}


Table 11. Maximum contaminant levels and minimum reporting levels of selected purgeable organic compounds in drinking water.

[Analyses were performed by the U.S. Geological Survey National Water Quality Laboratory (NWQL). Abbreviations: MCL, maximum contaminant level; MRL, minimum reporting level. MCL's were established pursuant to the recommendations of the U.S. Environmental Protection Agency (1994; 2000, p. 419) for community water systems and are included for comparison with results from this study. MRL's are from the NWQL website (http://nwql.cr.usgs.gov/usgs/ltmdl). Units are in micrograms per liter $(\mu \mathrm{g} / \mathrm{L})$. Symbol: **, MCL has not been established. Abbreviation: tthm, total trihalomethanes (trihalomethane analyses in this report include bromodichloromethane, dibromochloromethane, tribromomethane, and trichloromethane); MCL for thm is $100 \mu \mathrm{g} / \mathrm{L}$ (U.S. Environmental Protection Agency, 2003)]

\begin{tabular}{|c|c|c|}
\hline Purgeable organic compounds & MCL & MRL \\
\hline Acrylonitrile & $* *$ & 2.5 \\
\hline Benzene & 5 & .1 \\
\hline Bromobenzene & $* *$ & .2 \\
\hline Bromochloromethane & $* *$ & .2 \\
\hline Bromodichloromethane & tthm & .1 \\
\hline Bromomethane & $* *$ & .3 \\
\hline n-Butylbenzene & $* *$ & .2 \\
\hline sec-Butylbenzene & $* *$ & .2 \\
\hline tert-Butylbenzene & $* *$ & .2 \\
\hline 1,1,2-Trichlorotrifluoroethane (CFC-113) & $* *$ & .1 \\
\hline Chlorobenzene & 100 & .1 \\
\hline Chloroethane & $* *$ & .2 \\
\hline Chloromethane & $* *$ & .2 \\
\hline 2-Chlorotolulene & $* *$ & .2 \\
\hline 4-Chlorotolulene & $* *$ & .2 \\
\hline Dibromochloromethane & tthm & .2 \\
\hline 1,2-Dibromo-3-chloropropane (DBCP) & 0.2 & 1 \\
\hline Dibromomethane & $* *$ & .2 \\
\hline 1,2-Dibromoethane & $* *$ & .2 \\
\hline 1,2-Dichlorobenzene & 600 & .1 \\
\hline 1,3-Dichlorobenzene & $* *$ & .1 \\
\hline 1,4-Dichlorobenzene & 75 & .1 \\
\hline Dichlorodifluoromethane & $* *$ & .2 \\
\hline 1,1-Dichloroethane & $* *$ & .1 \\
\hline 1,2-Dichloroethane & 5 & .2 \\
\hline 1,1-Dichloroethene & 7 & .1 \\
\hline cis-1,2-Dichloroethene & 70 & .1 \\
\hline trans-1,2-Dichloroethene & 100 & .1 \\
\hline Dichloromethane & 5 & .2 \\
\hline 1,2-Dichloropropane & 5 & .1 \\
\hline 1,3-Dichloropropane & $* *$ & .2 \\
\hline 2,2-Dichloropropane & $* *$ & .2 \\
\hline 1,1-Dichloropropene & $* *$ & .2 \\
\hline cis-1,3-Dichloropropene & $* *$ & .2 \\
\hline trans-1,3-Dichloropropene & $* *$ & .2 \\
\hline Ethylbenzene & 700 & .1 \\
\hline Hexachlorobutadiene & $* *$ & .2 \\
\hline Isopropylbenzene & $* *$ & .2 \\
\hline 4-Isopropyltoluene & $* *$ & .2 \\
\hline Methyl tert-butylether & $* *$ & .2 \\
\hline Napthalene & $* *$ & .5 \\
\hline n-Propylbenzene & $* *$ & .2 \\
\hline Styrene & 100 & .1 \\
\hline
\end{tabular}




\section{$20 \quad$ Radiochemical and Chemical Constituents in Water from Selected Wells and Springs}

Table 11. Maximum contaminant levels and minimum reporting levels of selected purgeable organic compounds in drinking water. -Continued

\begin{tabular}{lcc}
\hline \multicolumn{1}{c}{ Purgable organic compounds } & MCL & MRL \\
\hline $1,1,1,2$-Tetrachloroethane & $* *$ & .2 \\
$1,1,2,2$-Tetrachloroethane & $* *$ & .2 \\
Tetrachloroethene & 5 & .1 \\
Tetrachloromethane (Carbon tetrachloride) & 5 & .2 \\
Tolulene & 1,000 & .1 \\
Tribromomethane (Bromoform) & tthm & .2 \\
1,2,3-Trichlorobenzene & $* *$ & .2 \\
$1,2,4,-$ Trichlorobenzene & 70 & .2 \\
$1,1,1-$ Trichloroethane & 200 & .1 \\
$1,1,2-$ Trichloroethane & 5 & .2 \\
Trichloroethene & 5 & .1 \\
Trichlorofluoromethane & $* *$ & .2 \\
Trichloromethane (Chloroform) & tthm & .1 \\
$1,2,3-$ Trichloropropane & $* *$ & .2 \\
1,2,4-Trimethylbenzene & $* *$ & .2 \\
1,3,5-Trimethylbenzene & $* *$ & .2 \\
Vinyl chloride & 2 & .2 \\
Xylenes, total ortho, meta, and para & 10,000 & .2 \\
\hline
\end{tabular}

Table 12. Maximum contaminant levels, laboratory reporting levels, and long-term method detection levels of selected insecticides in drinking water.

[Analyses were performed by the U.S. Geological Survey National Water Quality Laboratory (NWQL). Abbreviations: MCL, maximum contaminant level; LRL, laboratory reporting level; LT-MDL, long-term method detection level. MCL's were established pursuant to the recommendations of the U.S. Environmental Protection Agency (2000, p. 420-421) for community water systems and are included for comparison with results from this study. LRL's and LT-MDL's are from the NWQL web site (http://nwql.cr.usgs.gov/usgs/ltmdl). Units are in micrograms per liter ( $\mu \mathrm{g} / \mathrm{L})$. Symbol: **, MCL has not been established]

\begin{tabular}{llll}
\hline \multicolumn{1}{c}{ Insecticides } & MCL & LRL & LT-MDL \\
\hline Azinphos, methyl- & $* *$ & .05 & .02 \\
Carbaryl (Sevin) & $* *$ & .041 & .021 \\
Carbofuran & 40 & .02 & .01 \\
Chlorpyrifos (Dursban) & $* *$ & .005 & .003 \\
DDE, p,p'- & $* *$ & .0025 & .0013 \\
Diazinon & $* *$ & .005 & .003 \\
Dieldrin & $* *$ & .0048 & .0024 \\
Disulfoton (Disyston) & $* *$ & .021 & .011 \\
Ethoprophos & $* *$ & .005 & .002 \\
Fonofos & $* *$ & .0027 & .0013 \\
HCH, alpha- & $* *$ & .0046 & .0023 \\
Lindane (HCH, gamma-) & .2 & .004 & .002 \\
Malathion & $* *$ & .027 & .014 \\
Parathion & $* *$ & .01 & .005 \\
Parathion, methyl- & $* *$ & .006 & .003 \\
Permethrin, cis- & $* *$ & .006 & .003 \\
Phorate & $* *$ & .011 & .006 \\
Propargite & $* *$ & .023 & .011 \\
Terbufos & $* *$ & .017 & .009 \\
\hline
\end{tabular}


Table 13. Maximum contaminant levels, laboratory reporting levels, and long-term method detection levels of selected herbicides in drinking water.

[Analyses were performed by the U.S. Geological Survey National Water Quality Laboratory (NWQL). Abbreviations: MCL, maximum contaminant level; LRL, laboratory reporting level; LT-MDL, long-term method detection level. MCL's were established pursuant to the recommendations of the U.S. Environmental Protection Agency (2000, p. 420-421) for community water systems and are included for comparison with results from this study. LRL's and LT-MDL's are from the NWQL web site (http://nwql.cr.usgs.gov/usgs/ltmdl). Units are in micrograms per liter ( $\mu \mathrm{g} / \mathrm{L})$. Symbol: **, MCL has not been established]

\begin{tabular}{|c|c|c|c|}
\hline Herbicides & $\mathrm{MCL}$ & LRL & LT-MDL \\
\hline Acetochlor & $* *$ & .006 & .003 \\
\hline Alachlor & 2 & .0045 & .0022 \\
\hline Atrazine & 3 & .007 & .004 \\
\hline Atrazine, deethyl- (CIAT) & ** & .006 & .003 \\
\hline Benfluralin & $* *$ & .01 & .005 \\
\hline Butylate & ** & .002 & .001 \\
\hline Cyanazine & ** & .018 & .009 \\
\hline Dacthal (DCPA) & ** & .003 & .0015 \\
\hline 2,6-Diethylaniline & ** & .006 & .003 \\
\hline EPTC (Eptam) & $* *$ & .002 & .001 \\
\hline Ethalfluralin & ** & .009 & .005 \\
\hline Linuron & ** & .035 & .018 \\
\hline Metolachlor & ** & .013 & .006 \\
\hline Metribuzin & ** & .006 & .003 \\
\hline Molinate & ** & .0016 & .0008 \\
\hline Napropamide & ** & .007 & .003 \\
\hline Pebulate & ** & .0041 & .0021 \\
\hline Pendimethalin & $* *$ & .022 & .011 \\
\hline Prometon & ** & .015 & .007 \\
\hline Pronamide (Propyzamide) & $* *$ & .0041 & .0021 \\
\hline Propachlor & ** & .01 & .005 \\
\hline Propanil & $* *$ & .011 & .005 \\
\hline Simazine & 4 & .005 & .002 \\
\hline Tebuthiuron & $* *$ & .016 & .008 \\
\hline Terbacil & $* *$ & .034 & .017 \\
\hline Thiobencarb & $* *$ & .0048 & .0024 \\
\hline Triallate & $* *$ & .0023 & .0012 \\
\hline Trifluralin & ** & .009 & .005 \\
\hline
\end{tabular}




\section{Radiochemical and Chemical Constituents in Water from Selected Wells and Springs}

Table 14. Concentrations of selected herbicides in water from selected wells and springs, eastern Snake River Plain.

[See figure 2 for location of sites. Analyses were performed by the U.S. Geological Survey National Water Quality Laboratory. Units are in micrograms per liter $(\mu \mathrm{g} / \mathrm{L})$. Symbols: <, concentration less than the laboratory reporting level (used to indicate that the detection of the constituent is unclear); *, quality-assurance sample (MV-8 is a replicate of MV-1); E, estimated result (a result may be estimated for a variety of laboratory-specific reasons; for instance, the result may lie outside the calibrated range of the instrument; estimated results have increased uncertainty (Childress and others, 1999, pp. 8-10)). Concentrations of herbicides listed in table 13, but not in table 14, were less than the laboratory reporting level in all samples]

\begin{tabular}{|c|c|c|c|c|}
\hline Site identifier & Atrazine & Deethyl atrazine & Metolachlor & Simazine \\
\hline$\overline{M V-1}$ & $<.007$ & $.0026 \mathrm{E}$ & $<.013$ & $<.005$ \\
\hline MV-8* & $.0031 \mathrm{E}$ & $.0027 \mathrm{E}$ & $<.013$ & $<.005$ \\
\hline MV-11 & .0116 & $.0142 \mathrm{E}$ & $<.013$ & .0063 \\
\hline MV-15 & $<.007$ & $.0043 \mathrm{E}$ & $<.013$ & $<.005$ \\
\hline MV-18 & $.0042 \mathrm{E}$ & $.0064 \mathrm{E}$ & $<.013$ & $<.005$ \\
\hline MV-21 & $.0037 \mathrm{E}$ & $.0041 \mathrm{E}$ & $<.013$ & $<.005$ \\
\hline MV-23 & .0206 & $.0140 \mathrm{E}$ & $<.013$ & .0155 \\
\hline MV-24A & .0106 & $.0115 \mathrm{E}$ & $<.013$ & .0055 \\
\hline MV-25 & .0119 & $.0069 \mathrm{E}$ & $.0038 \mathrm{E}$ & $.0029 \mathrm{E}$ \\
\hline MV-26 & $<.007$ & $<.006$ & $<.013$ & $<.005$ \\
\hline MV-29 & $<.007$ & $<.006$ & $<.013$ & $<.005$ \\
\hline MV-30 & $.0032 \mathrm{E}$ & $.0046 \mathrm{E}$ & $<.013$ & $<.005$ \\
\hline MV-35 & $<.007$ & $<.006$ & $<.013$ & $<.005$ \\
\hline MV-37 & $<.007$ & $.0054 \mathrm{E}$ & $<.013$ & $<.005$ \\
\hline MV-40 & $<.007$ & $<.006$ & $<.013$ & $<.005$ \\
\hline MV-41 & .0099 & $.0195 \mathrm{E}$ & $<.013$ & $<.005$ \\
\hline MV-59 & $<.007$ & $<.006$ & $<.013$ & $<.005$ \\
\hline MV-61 & $<.007$ & $<.006$ & $<.013$ & $<.005$ \\
\hline
\end{tabular}

